\author{
Wolfgang Stinnesbeck - Gerta Keller - Thierry Adatte \\ Markus Harting · Doris Stüben · Georg Istrate \\ Utz Kramar
}

\title{
Yaxcopoil-1 and the Chicxulub impact
}

Received: 28 August 2003/ Accepted: 11 July 2004 / Published online: 29 October 2004

(C) Springer-Verlag 2004

\begin{abstract}
CSDP core Yaxcopoil-1 was drilled to a depth of $1,511 \mathrm{~m}$ within the Chicxulub crater. An organic-rich marly limestone near the base of the hole $(1,495$ to $1,452 \mathrm{~m}$ ) was deposited in an open marine shelf environment during the latest Cenomanian (uppermost Rotalipora cushmani zone). The overlying sequence of limestones, dolomites and anhydrites $(1,495$ to $894 \mathrm{~m})$ indicates deposition in various carbonate platform environments (e.g., sabkhas, lagoons). A 100-m-thick suevite breccia (894-794 m) identifies the Chicxulub impact event. Above the suevite breccia is a dolomitic limestone with planktic foraminiferal assemblages indicative of Plummerita hantkeninoides zone CF1, which spans the last $300 \mathrm{ky}$ of the Maastrichtian. An erosional surface $50 \mathrm{~cm}$ above the breccia/dolomite contact marks the $\mathrm{K} / \mathrm{T}$ boundary and a hiatus. Limestones above this contact contain the first Tertiary planktic foraminifera indicative of an upper P. eugubina zone P1a(2) age. Another hiatus $7 \mathrm{~cm}$ upsection separates zone $\mathrm{P} 1 \mathrm{a}(2)$ and hemipelagic limestones of planktic foraminiferal Zone P1c. Planktic foraminiferal assemblages of Zone Plc to P3b age are present from a depth of 794.04 up to $775 \mathrm{~m}$. The Cretaceous carbonate sequence appears to be autochthonous, with a stratigraphic sequence comparable to late Cretaceous sediments known from outside the Chicxulub crater in northern and southern Yucatan, including the late
\end{abstract}

W. Stinnesbeck $(\bowtie)$

Geologisches Institut, Universität Karlsruhe,

76128 Karlsruhe, Germany

E-mail: wolfgang.stinnesbeck@bio-geo.uni-karlsruhe.de

G. Keller

Department of Geosciences, Princeton University, Princeton, NJ 08544, USA

T. Adatte

Geological Institute, University of Neuchâtel,

2007 Neuchâtel, Switzerland

M. Harting · D. Stüben · G. Istrate · U. Kramar

Institut für Mineralogie und Geochemie, Universität Karlsruhe, 76128 Karlsruhe, Germany
Cenomanian organic-rich marly limestone. There is no evidence that these sediments represent crater infill due to megablocks sliding into the crater, such as major disruption of sediments, chaotic changes in lithology, overturned or deep dipping megablocks, major mechanical fragmentation, shock or thermal alteration, or ductile deformation. Breccia units that are intercalated in the carbonate platform sequence are intraformational in origin (e.g., dissolution of evaporites) and dykes are rare. Major disturbances of strata by the impact therefore appear to have been confined to within less than $60 \mathrm{~km}$ from the proposed impact center. Yaxcopoil-1 may be located outside the collapsed transient crater cavity, either on the upper end of an elevated and tilted horst of the terrace zone, or even outside the annular crater cavity. The Chicxulub site thus records a large impact that predates the $\mathrm{K} / \mathrm{T}$ boundary impact and mass extinction.

Keywords Chicxulub - Impact crater $\cdot \mathrm{K} / \mathrm{T}$ boundary . Mexico $\cdot$ Biostratigraphy

\section{Introduction}

The circular Chicxulub structure in Yucatan, Mexico, represents a "complex multi-ring impact crater", which is widely credited to prove the Alvarez et al. (1980) hypothesis that a single asteroid caused the mass extinction of the dinosaurs and other organisms at the Cretaceous-Tertiary $(\mathrm{K} / \mathrm{T})$ boundary. The structure is buried several hundred metres beneath the surface, with the Yucatan coastline passing approximately through the center of the crater (Fig. 1). The Chicxulub Scientific Drilling Project (CSDP) supported by the International Continental Scientific Drilling Program (ICDP) aimed at (1) identifying the lithology and structure of the Chicxulub crater, (2) determining the precise age and environmental effects of the impact, and (3) understanding the cratering process for large body impacts. In addition, 


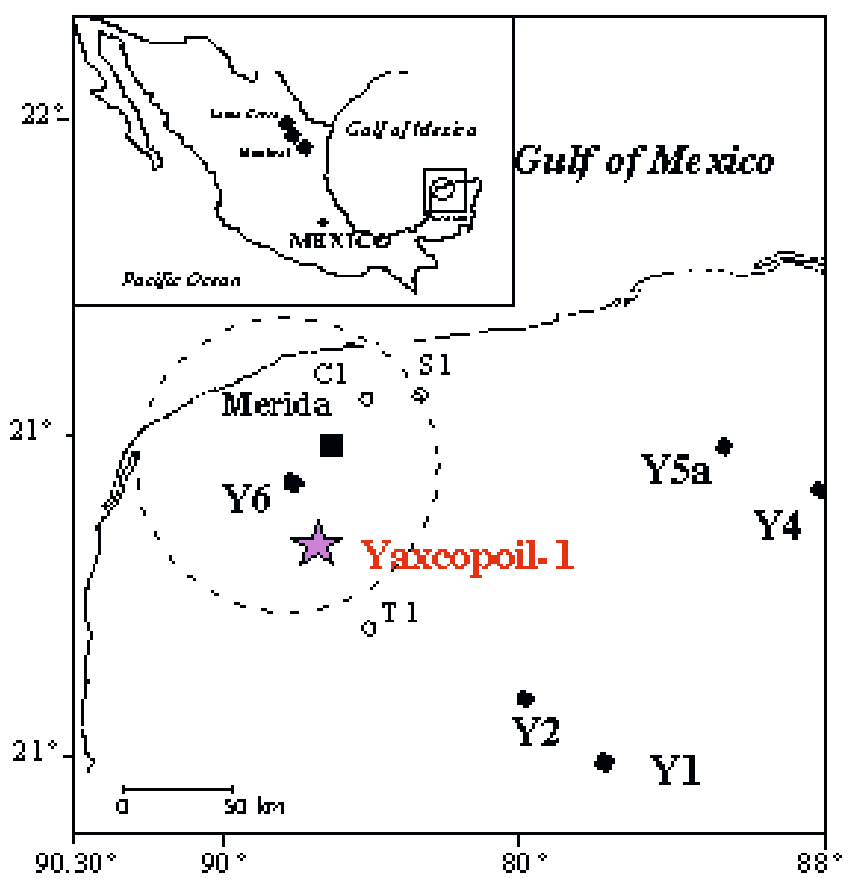

Fig. 1 Map of the Yucatan peninsula showing location of the Chicxulub impact crater (circle) and of PEMEX and CSDP wells discussed in text. Y-wells $=$ Yucatan Nos. 1, 2, 4, 5a and 6; Cwell $=$ Chicxulub Nr. 1; S-well $=$ Sacapuc Nr. 1; T-well $=$ Ticul Nr. 1; Yax $=$ Yaxcopoil-1

the project emphasised the role of interplanetary collisions in the geological and biological evolution of the earth. To this end, Yaxcopoil-1 was continuously cored within the Chicxulub crater between December 2001 and February 2002 and recovered a continuous sequence of sediments cored through impact-generated breccias into pre-impact lithologies.

Although the petrography and geochemistry of glass, melt rock and exotic breccia clasts of the Chicxulub impact crater are well known, the pre- and post-impact sequence is poorly dated due to predominantly shallow water carbonate platform sediments of pre-impact strata and unavailable samples for critical post-impact strata (Ward et al. 1995). Prior to the Yaxcopoil-1 well, knowledge of the pre-impact lithologies in the crater area was essentially restricted to a few cores and logs of Petroleos Mexicanos (PEMEX) wells drilled in the 1960s (Lopez Ramos 1973, 1975; Ward et al. 1995). Wells drilled in the 1990s by UNAM penetrated Tertiary limestones and the impact breccia unit, but did not reach older sediments (e.g., Sharpton et al. 1996; Urrutia et al. 1996, 2001; Rebolledo Vieyra et al. 2000; Morgan et al. 2002). Consequently, there are large error margins in studies estimating (a) the crater diameter between 180 and $300 \mathrm{~km}$ (e.g., Boynton 1991; Hildebrand et al. 1991; Sharpton et al. 1996; Morgan and Warner 1999), (b) models predicting environmental consequences of the Chicxulub impact on a carbonate platform, such as the dust cloud generated or the amount of sulfate released by the vaporization of the underlying gypsum and anhydrite (e.g., Brett 1992; Sigurdsson et al. 1992; Ivanov et al. 1996; Pope et al.1997; Pierazzo et al. 1998; Kring 2000; Pope 2002). (c) Similarly, there is uncertainty regarding the precise age of the Chicxulub impact event due to scarce biostratigraphic data from inside and around the Chicxulub crater. A K/T age for the Chicxulub impact is largely based on geochemical correlation of melt rock with microtektites in Haiti and northeastern Mexico and an ${ }^{40} \mathrm{Ar} /{ }^{39} \mathrm{Ar}$ age of $65.0 \pm 0.2 \mathrm{Ma}$ (Izett, 199 1; Sigurdsson et al. 199 1; Swisher et al. 1992). This has led to the assumption that the Chicxulub impact occurred precisely at the $\mathrm{K} / \mathrm{T}$ boundary and is therefore the long sought impact that caused the end-Cretaceous mass extinction. The new core Yaxcopoil-1 was expected to provide more definite answers to all the outstanding questions.

The drill site Yaxcopoil-1 (Yax-1) is located $40 \mathrm{~km}$ southwest of Merida, Mexico, approximately $60 \mathrm{~km}$ from the center of the Chicxulub structure and between the existing PEMEX wells Yucatan-6 and Ticul-1 (Fig. 1). Although no seismic profiles were available from the area, the location of Yax-1 was chosen in the belief that the transient cavity of the impact crater and the outer part of an annular trough, which surrounds a peak ring of $40 \mathrm{~km}$, would be drilled. Hence, the well was expected to penetrate several hundred metres of suevite overlying a coherent impact melt sheet (Dressler et al. 2003).

This study reports on the stratigraphy, lithology, mineralogy and depositional environment of the Yaxcopoil-1 core from its base to $20 \mathrm{~m}$ above the impact breccia $(774.65 \mathrm{~m})$. The main objectives of this investigation include examination of: (1) the stratigraphic sequence and nature of deposition (chaotic vs. normal), (2) the stratigraphic position and thickness of the impact breccia, (3) the stratigraphic position of the $\mathrm{K} / \mathrm{T}$ boundary, (4) the depositional environment before and after the impact, and (5) the crater depth.

\section{Methods}

The Yaxcopoil-1 cores were measured and examined for lithological changes, macrofossils, trace fossils, bioturbation, erosion surfaces and hardgrounds. A total of 180 samples were analyzed for microfacies, microfossils, mineralogy and geochemistry This report concentrates on the sedimentary sequence between 775 and $1,511 \mathrm{~m}$. In the limestone interval above the impact, breccia samples were analyzed at $5-\mathrm{cm}$ intervals for the first $70 \mathrm{~cm}$, and 10 to $20-\mathrm{cm}$ intervals $2.5 \mathrm{~m}$ upsection. For foraminiferal studies, samples were processed following the standard method of Keller et al. (1995) and washed through a $63-\mu \mathrm{m}$ screen, with the smaller $(36-63 \mu \mathrm{m})$ size fraction separated and oven dried for the examination of tiny specimens. Planktic and benthic foraminifera are too recrystallised in the dolomitic limestone overlying the impact breccia and were therefore analyzed in thin sections. Preservation is better in the early Danian, though 
planktic foraminifera are very fragile due to dissolution and diagenetic alteration. Therefore, both the thin section and washed residues were examined.

For geochemical and mineralogical analyses, the samples were dried, crushed, finely ground in an agate mill, and dried at $105^{\circ} \mathrm{C}$. Clay mineral analyses were conducted at the Geological Institute of the University of Neuchatel, Switzerland, based on XRD analyses (SCINTAG XRD 2000 Diffractometre). Sample processing followed the procedure outlined by Kübler (1987) and Adatte et al. (1996). Total organic content (TOC) analysis was performed with a Rock-Eval 6 pyrolyser on powdered bulk samples, based on the analytical methods of Espitalié et al. (1986) and Lafargue et al. (1996).

For selected samples, energy-dispersive (EDS) electron microprobe analyses and back-scattered electron (BSE) images were performed on polished thin sections at the Laboratory for Electron Microscopy, University of Karlsruhe, using a CAMECA SX-50 microprobe according to methods outlined in Reed (1996). All quantitative major element analyses were calibrated with internal standards. Detection limits are in the range between 0.5 and $1 \mathrm{wt} \%$.

Iridium was analyzed by instrumental neutron activation analysis INAA at the Institute for Mineralogy and Geochemistry, University of Karlsruhe. Approximately $200 \mathrm{mg}$ of each sample was sealed in SUPRASIL quartz ampoules. The quartz was packed in a cadmiumcovered irradiation capsule to shield the thermal neutrons and irradiated for $24 \mathrm{~h}$ at an epithermal neutron flux of $1.2 \times 10^{12} \mathrm{~cm}^{-2} \mathrm{~s}^{-1}$. After a decay time of $>10$ days, the Ir was determined by coincidence spectrometry of the 308 and $316 \mathrm{keV}$ lines. Using a measuring time of $40,000 \mathrm{~s}$ detection limits of $40 \mathrm{pg} / \mathrm{g}$ could be achieved.

Stable carbon and oxygen isotope data were obtained from bulk rock samples at the Institute for Mineralogy and Geochemistry at Karlsruhe using a fully automated preparation system (MultiCarb) connected on-line to an isotope ratio mass spectrometre (Optima, Micromass Limited UK). All carbon and oxygen isotope values are reported relative to the V-PDB standard, and the precision was better than $0.06 \%$ for $\mathrm{d}^{13} \mathrm{C}$ and $<0.1 \%$ for $\mathrm{d}^{18} \mathrm{O}$.

\section{Results}

Stratigraphy and facies of CSDP-drill core Yaxcopoil-1

A continuous sequence of cores was recovered in CSDP well Yaxcopoil-1 from 400 to $1,511 \mathrm{~m}$. Platform carbonates and pelagic marly limestones overlie a 100m-thick suevitic breccia (794-894 m), which overlies limestones, dolomites and anhydrites (894 to $1,511 \mathrm{~m}$ ). Within the sequence analysed, from 775 to $1,511 \mathrm{~m}$, we identified 10 major bio- and lithostratigraphic units (Units A-K; Fig. 2).
Fig. 2 Lithology, biostratigraphy, and inferred paleoenvironmental changes at the Yaxcopoil-1 well, northern Yucatan. Note that 10 major litho- and biostratigraphic units were identified between 775 and $1,511 \mathrm{~m}$ depth

Unit A; $1,495-1,511 \mathrm{~m}$

Unit A consists of a 16-m-thick breccia with minor stratiform interlayers of dolomite and anhydrite at the base of the core from 1,511 to 1,495 m (Fig. 2). Breccia clasts consist of dolomite, dolomitic limestones and anhydrite $(<10 \%)$. Some breccia layers indicate an in situ brecciation of dolomite with angular clasts and voids filled by fine-grained calcareous cement, whereas other breccia layers contain isolated clasts floating in a fine-grained dolomitic limestone matrix. These stratiform breccias may result from "chicken-wire" processes (e.g., Boggs 1987) affecting the dolomite-anhydrite sequence. Lithologies and microfacies indicate restricted interior carbonate platform environments and show no evidence for exotic input, such as glass or basement clasts that could indicate an impact origin.

\section{Unit B; 1,452-1,495 m}

Unit B consists of a 42-m-thick grey to dark grey marly, bituminous, bedded and laminated limestone that spans from 1,495 to about $1,452 \mathrm{~m}$ (Fig. 2, Fig. 3, 5). Thin section analyses (samples 1851-1858) reveal bioclastic wackestones (biomicrites) with rare (near the base) to abundant (upper part) planktic foraminifera (e.g., Whiteinella archaeocretacea, W. baltica, Rotalipora cushmanni, R. greenhornensis, Hedbergella spp.; Fig. 4, 20-26), rare pelagic crinoids (Fig. 3, 1), filaments, and calcispheres. Planktic foraminiferal faunas indicate an uppermost Cenomanian (top of $R$. cushmani zone) age and deposition in a low-oxygen open marine environment that is indicative of ocean anoxic event 2 (OAE2) which characterizes the latest Cenomanian (e.g., Schlanger et al. 1987). Similar microfacies and faunas have previously been documented for Pemex wells of northern Yucatan by Ward et al. (1995) and correlated with the OAE2 (Bonarelli event) (Jarvis et al. 1988). This correlation is confirmed by high TOC content $(>7 \%)$, which characterizes this anoxic event globally. Moreover, the high hydrogen index (700-770 $\mathrm{mg} \mathrm{HC} / \mathrm{g}$ TOC) and extremely low-oxygen index (5-9 mg C02/gTOC) point to marine organic matter which is characteristic of OAE2.

Unit C; $1,452-1,315 \mathrm{~m}$

Unit C consists of a 137-m-thick predominantly grey, layered dolomite with several layers of stratiform breccia and bituminous beds with small anhydrite nodules $(<10 \mathrm{~cm}$ in diameter). Layered anhydrite and dolomite 


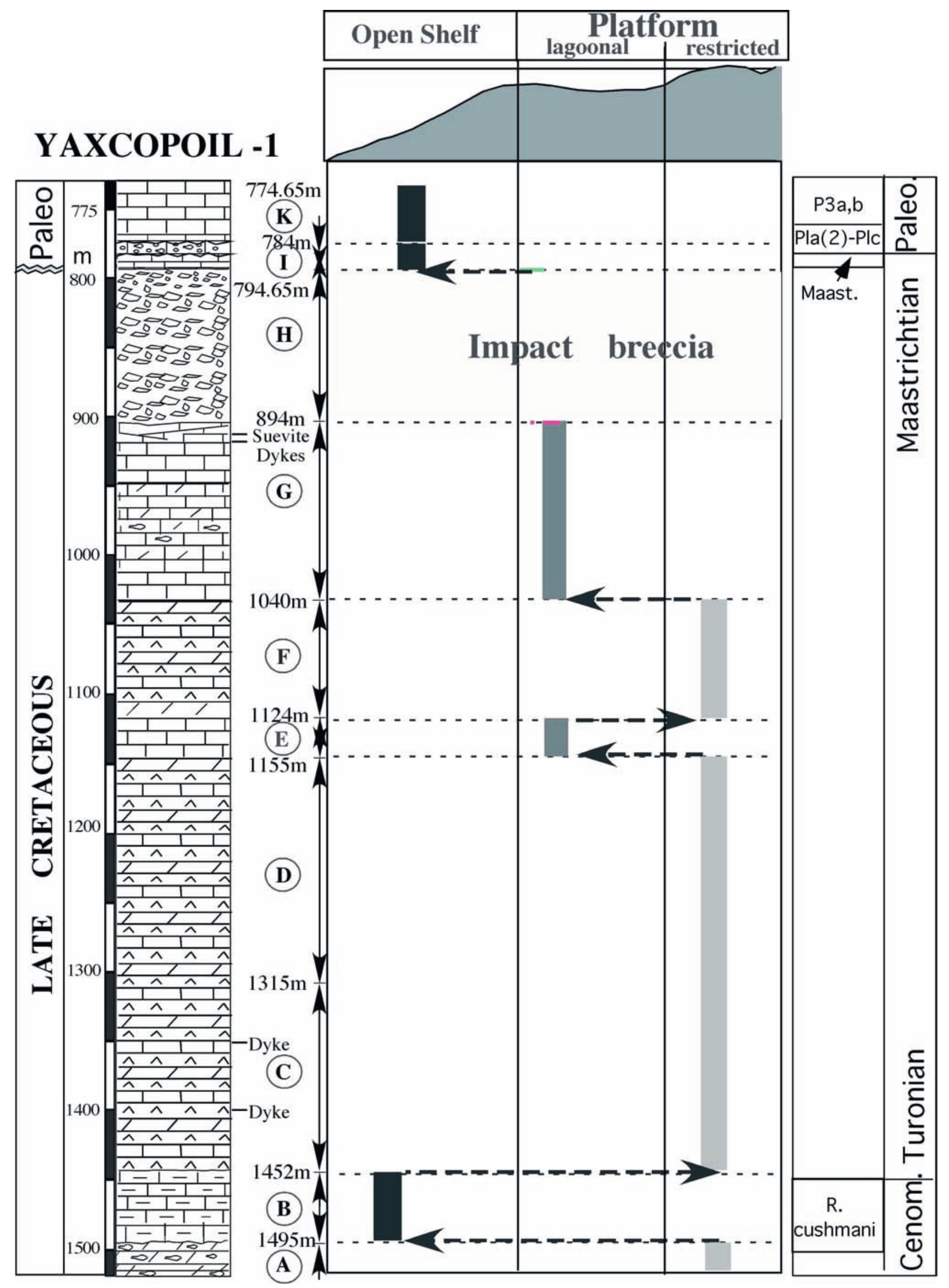


layers are present between 1,429 and 1,444 $\mathrm{m}$ in a very bituminous interval. Several dolomite layers are bioturbated and others show stromatolitic lamination due to cyanophycean bacteria. Fossils are rare in this unit and restricted to bivalve fragments (? oysters) and benthic foraminifers (e.g., miliolids), which occur in peloidal packstones and grainstones (Fig. 3, 3). Most dolomitic layers, however, appear to be due to diagenetic transformation of lime-mudstones. The brecciated intervals occur repeatedly throughout the 137-m-thick unit C and are intraformational, usually showing stratiform contacts with the under- and overlying dolomite layers. Clasts consist of dolomite, dolomitic limestones (e.g., mudstones, peloidal packstones, grainstones) and anhydrite $(<10 \%)$. Some breccia layers reveal in situ brecciation of dolomite as indicated by angular dolomite clasts and voids filled by fine-grained calcareous cement, similar to breccias of unit A. Some layers contain isolated clasts, "floating" in a fine-grained dolomitic limestone matrix. No extraformational lithologies (e.g., basement clasts) and no exotic minerals or glass were observed.

The layered dolomite and stratiform breccia layers of unit $\mathrm{C}$ indicate deposition occurred in a restricted inte-
Fig. 31 Planktic crinoid, late Cenomanian Rotalipora cushmani zone (Unit B, sample 1851); 2 Biopelsparite with benthic foraminifer (Unit $\mathrm{G}$, sample 708); 3 Miliolid foraminifer (Unit C, sample 1863); 4 Bioclastic grainstone with benthic foraminifer (Unit G, sample 1885); 5 Laminated planktic foraminiferal wackestone, late Cenomanian $R$. cushmani zone (sample 1854); 6 Polymict breccia (base of suevitic breccia Unit $\mathrm{H}$, sample 1894); 7 Planktic foraminiferal wackestone, Unit I, sample 954); 8 Clast of planktic foraminiferal wackestone of zone P1c age floating in planktic foraminiferal wackestone of middle Paleocene Zone P3a age (Unit H, sample 964); 9 Detail of 8 : Planktic foraminifer (Parasubbotina pseudobulloides) in clast of Zone P1c age (Unit $\mathrm{H}$, sample 964). $10-11$ Bioclastic grainstone with red algal fragment (11) and benthic foraminifera (miliolids and textulariids) of shallow water carbonate platorm origin (Unit $\mathrm{H}$, sample 971); $12-13$ Grainstone with bioclasts of open marine planktic foraminifera (e.g., Subbotina triloculinoides) and shallow water carbonate platform origin (e.g., echinoids, red algae, bivalves) (Unit H, sample 972)
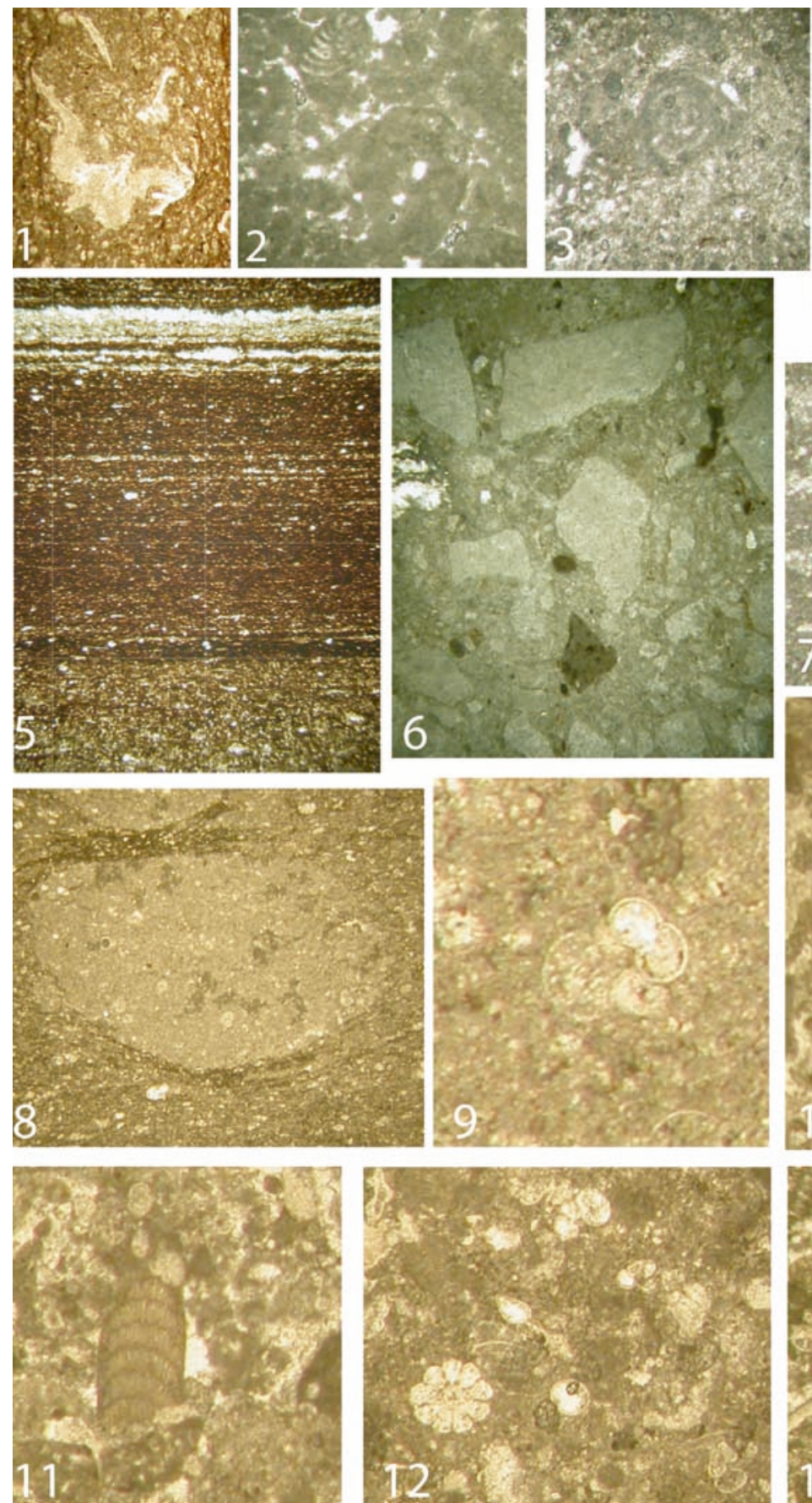
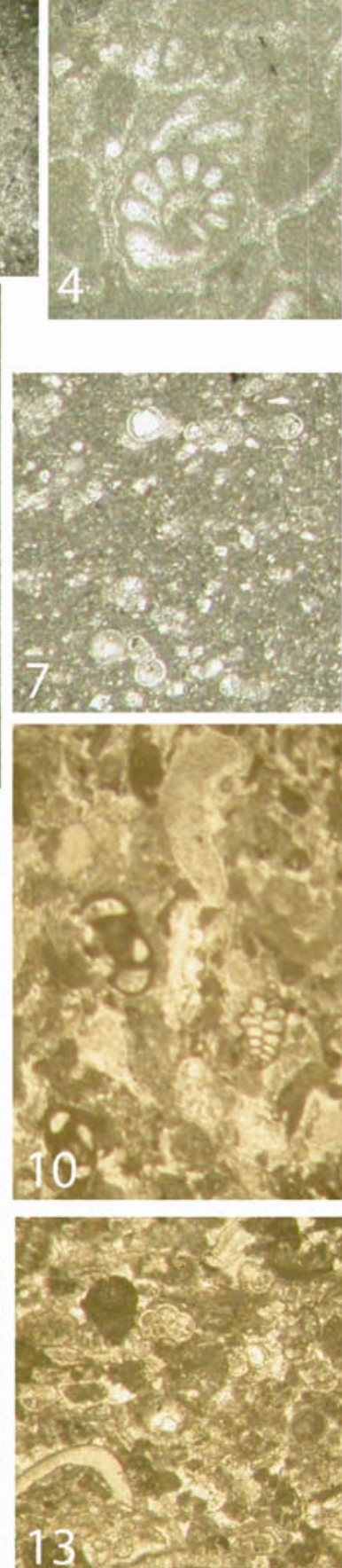
rior carbonate platform environment once again (Fig. 2). Dolomites were likely deposited in a very shallow subtidal to intertidal environment, as also indicated by the presence of mudstone lithologies, anhydrite nodules, laminated dolomite of likely stromatolitic origin, and the generally low frequency of megafossils (only rare bivalve fragments). Very rare miliolids are the only benthic foraminifera recovered from this interval. A $15-\mathrm{m}$-thick bed of alternating anhydrite and dolomite $(1,429-1,444 \mathrm{~m})$ within unit C indicates deposition in a sabkha environment. These conditions are confirmed by the presence of palygorskite, a fibrous clay mineral, which typically develops in sabkha environments (Chamley 1989; Keller et al. 2003a, 2003b). The presence of this clay mineral indicates that this unit did not suffer from strong thermal alteration. The breccia intervals likely formed within this restricted inner platform environment, as indicated by the absence of any lithologies external to and older than unit $\mathrm{C}$.

Unit $\mathrm{D} ; 1,315$ to $1,155 \mathrm{~m}$

Unit $\mathrm{D}$ is $160 \mathrm{~m}$ thick and characterised by abundant anhydrite layers ranging from 2 to $11 \mathrm{~m}$ thick, with interlayers of minor dolomite and dolomitic limestone ranging from a few decimetres to $2 \mathrm{~m}$ thick. The contact with the underlying unit $\mathrm{C}$ is conformable and transitional. Most of the anhydrite layers are grey and massive, but a few are laminated. Anhydrite nodules occur in the dolomite. Rare breccia layers of anhydrite and dolomite are present and likely represent collapse breccias that formed by the dissolution of evaporites and carbonates, which are typical components of carbonate platform environments.

About $10 \%$ of unit $\mathrm{D}$ consists of dolomite layers. These dolomites are beige to yellow and occasionally contain stromatolitic lamination and bird's-eye structures. Megafossils are very rare, and only a single small gastropod was recognised at a depth of $1,179 \mathrm{~m}$. Dolomite microfacies reveal mudstone lithologies as the original sediment deposition prior to dolomitization. This suggests that the dolomite and anhydrite layers of unit D were deposited in a restricted interior platform or sabkha environment with an intertidal to supratidal evaporitic setting (Fig. 2). Sabkha conditions are also indicated by the presence of palygorskite, similar to unit C.

Unit E; 1,124-1,155 m

Unit $\mathrm{E}$ is $19 \mathrm{~m}$ thick and consists of white and grey chalky limestone and tan dolomitic limestone with rare gypsum crystals and anhydrite nodules. No anhydrite layers are present. These muddy limestones are largely free of fossils. However, there are some peloidal packstones and bioclastic wackestones that contain frag- ments of (? ostreid) bivalves and rare miliolids. These lithologies indicate that sediment deposition continued in an inner platform environment, such as a shallow subtidal setting where evaporation only rarely reached precipitation of gypsum or anhydrite (Fig. 2).

Unit F; $1,040-1,124 \mathrm{~m}$

Unit $\mathrm{F}$ is $84 \mathrm{~m}$ thick and consists of thick massive grey anhydrite alternating with grey, tan and yellow dolomitic limestones and dolomites with rare anhydrite nodules. A few breccia layers up to $1 \mathrm{~m}$ thick are interbedded and consist of a mixture of dolomite and anhydrite clasts "floating" in a fine-grained matrix. Dolomite layers are occasionally laminated and a single layer at $1,100.5 \mathrm{~m}$ shows cross-bedding. Bioturbation is common as evident by chondrites but these muddy limestones are largely devoid of fossils. Deposition occurred in a sabkha environment, where occasional collapsed breccia layers formed due to dissolution of evaporites and carbonates (Fig. 2).

Unit G; 894-1,040 m

Unit $\mathrm{G}$ is $146 \mathrm{~m}$ thick and consists of tan and grey dolomite layers, light grey dolomitic limestone layers and limestones. Anhydrite is absent. Limestone textures are dominated by peloidal packstones and grainstones, but wackestones with benthic foraminifers (e.g., lenticulinids, miliolids; Fig. 3, 2, 4) and ostracods are also common. In addition to these microfossils, several layers (e.g., 959 and $952 \mathrm{~m}$ ) contain angular shell fragments of bivalves (? oysters).

These lithologies and fossils suggest a shallow water platform environment. The presence of peloidal grainstones (Fig. 3, 2, 4) and packstones, the abundance of benthic miliolid and lenticulinid foraminifers and rare bivalves all suggest a shallow subtidal setting with occasional currents. The depositional environment is thus less restricted than in units $\mathrm{C}$ to $\mathrm{F}$ and appears to be lagoonal or even open marine (Fig.2).

Breccia layers are rare in unit $G$, but have been identified in a dolomitic interval at $1,005 \mathrm{~m}$ depth $(1 \mathrm{~m}$ thick), and between 991 and $989 \mathrm{~m}$, where a 1-m-thick breccia overlies a brown celular porous dolomite ("zellendolomite"). In both breccia layers, the clasts consist of dolomite and voids are filled with dolomite crystals. These are thus collapse breccias, as also indicated by the absence of diverse lithologies, or exotic components, such as basement rocks, glass, or clayminerals related to the weathering of glass (e.g., wellcrystallised smectite of Cheto type; Keller et al. 2003b).

\section{Unit H; 794.60-894 m}

Unit $\mathrm{H}$ is a $100-\mathrm{m}$-thick suevite impact breccia with erosive lower and upper contacts (Fig. 2). Clasts are 

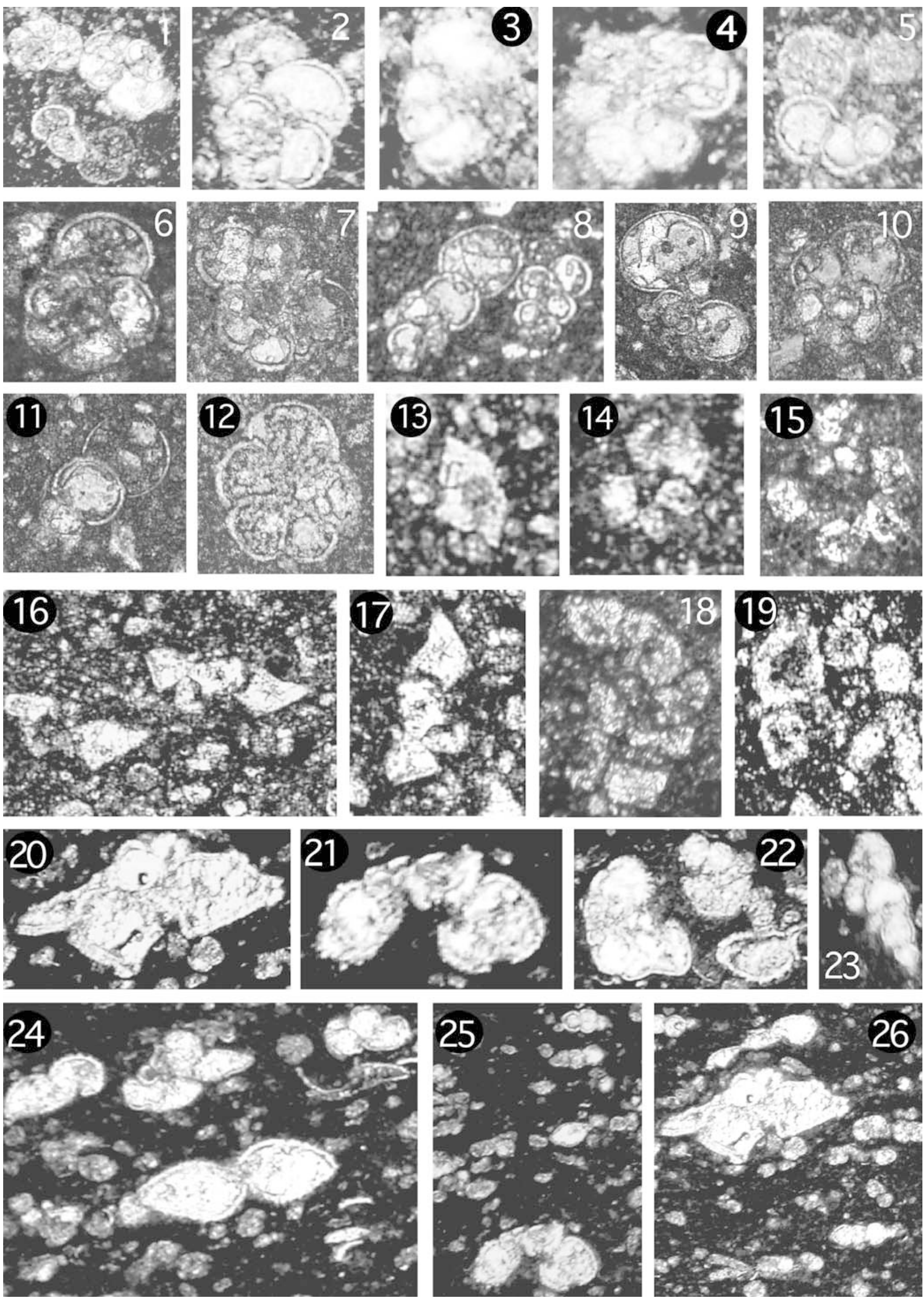
Fig. 4 Thin section micrographs of late Cretaceous and early Tertiary planktic foraminifera from Yaxcopoil-1. Late Paleocene zone P3a: 1 Praemurica uncinata (sample 959); 2 Morozovella acuta (sample 959); 3 Morozovella angulata (sample 969); 4, $5 \mathrm{M}$. praecursoria (sample 969). Early Paleocene Subzones P1a and P1c: 6 Planorotaloides compressa (sample 3), 7 Morozovella inconstans (sample 4); 8 Woodringina hornerstownensis (sample 1); 9, 10 Parasubbotina pseudobulloides (samples 5, 7). $11 \mathrm{~W}$. hornerstownensis (sample 7); 12 Parvularugoglobigerina eugubina (sample 7) upper zone Pla. Late Maastrichtian zone CF1: 13 Plummerita hantkeninoides (sample 20), 14 Rugoglobigerina macrocephala (sample 20), $15 R$. rugosa (sample 20); 16, 17 Globotruncana insignis (?), 18 Rosita contusa (sample 10); 19 Rugoglobigerina rugosa (sample 20). Late Cenomanian OAE2 event: upper Rotalipora cushmani zone, sample 1857; 20 Rotalipora greenhornensis; 21 Rotalipora cushmani; 22 Whiteinella paradubia; 23 Heterohelix moremani; 24 Current bedded $W$. archeocretacea, Hedbergella simplex; $25 \mathrm{R}$. cushmani and small heterohelicids and guembelitrids; 26 R. greenhornensis and small species

angular to subrounded and average a few $\mathrm{cm}$ in diameter (Fig. 3, 6), though larger clasts up to $1 \mathrm{~m}$ in diameter are present. It is a polymict breccia that contains clasts of dolomite, limestone (e.g., with benthic foraminifers) and rare sandstones. The amount of anhydrite clasts is difficult to establish in this core, but appears to be low. Ward et al. (1995), on the other hand, estimated their contents to make up 15-20\% in the impact breccias of PEMEX wells outside the immediate Chicxulub crater. In addition to undigested clasts of the Mesozoic sediment cover of northern Yucatan, there are minor but significant constituents of melt rock, and crystalline rocks of continental basement origin, such as granite, granodiorite, gneisses, quartzite, albite-green schists and micaschists.

Within these deposits, grey-green fragments are common along with spherules of glass altered to well-crystallised smectite. Some silicate melt clasts show fluidal textures and domains of variable chemical compositions, while others are cryptocrystalline and show spherulitic textures typical of devitrification. Quartz and feldspar xenocrysts with planar deformation lamellae are also common and indicate shock deformation (e.g., samples 1895, 1899; Fig. 5, 5, 6). We observed no evidence for typical volcanic textures or minerals in this breccia.

Clasts have different diagenetic histories. Limestone and dolomite clasts frequently show thermal alteration, i.e. altered rims, and still others show no alteration with microfacies intact. Glass is always devitrified and the entire unit $\mathrm{H}$ shows hydrothermal alteration subsequent to deposition as also indicated by the presence of K-feldspars, albite, apatite, zeolites and pyrite. Minor amounts of gypsum, chlorite-smectite, opal-CT, sepiolite, kaolinite and illite are also present.

The polymict character of the breccia, the abundance of melt fragments and altered glass and the common presence of shocked minerals indicates that unit $\mathrm{H}$ is similar to the "suevite" impact melt rock from the German Ries crater (eg., Stöffler, in Dressler et al. 2003). Breccia unit $\mathrm{H}$ is the only bonafide impact breccia recovered in the Yacopoil-1core of the Chicxulub crater.
Most of the unit is considered to be a ballistic air fall deposit, but turbulent nuée ardente -like and groundsurge suevite deposits (basal $10 \mathrm{~m}$ ) may also be present (e.g., Dressler et al. 2003; Stöffler et al. 2003).

The top $15 \mathrm{~m}$ of the breccia unit $\mathrm{H}$ was deposited by current transport as indicated by layered breccias with alternating layers of small and larger subrounded to rounded clasts, fining upward and sorting of clasts. Devitrified glass is abundant and often characterised by pumice-like "fiame"-structures. Other clasts include dolomite, fossiliferous limestone and isolated fossils (e.g., benthic foraminifers, bivalves), quartz with undulose extinction and albite-sericite-bearing schists (? metamorphic origin). Microcline feldspars suggesting an origin from granite or gneiss, orthoclase and zeolites are also common and underline the polymict suevitic nature of this sediment. Geochemical composition of devitrified melt clasts suggests an andesitic composition, (e.g., sample 724, at $795.5 \mathrm{~m}$ ), with Si between 54-56\%, Al between $19-21 \%$, Fe between $5-8 \%$ and $\mathrm{Ca}>\mathrm{Mg}$ and $\mathrm{Na}$.

The general upward-fining trend recognised in the upper $15 \mathrm{~m}$ of unit $\mathrm{H}$ ranges from maximum clast diameters of 3-5 cm at the base of the member to about 2-5 mm near the top. Horizontal layering and coarse cross-bedding structures in the uppermost metre suggest reworking (box 178), as also indicated by alternating friable grey sand layers (clasts of approx. $2 \mathrm{~mm}$ ) with slightly larger (clasts $2-5 \mathrm{~mm}$ ) microconglomeratic horizons (Fig. 6). This 15-m-thick layered and upward fining breccia sequence reveals characteristic features of reworking and transport by currents after deposition of the impact breccia.

\section{Unit I; 784-794.60 m}

Unit $\mathrm{I}$ is approximately $10 \mathrm{~m}$ thick and consists of dolomitic limestone and limestone (Figs. 2, 6). The unit overlies an undulatory and erosive upper surface of unit $\mathrm{H}$ (Fig. 6). At this contact $(794.60 \mathrm{~m}$, in box 178 ; $794.54-794.60 \mathrm{~m}$ ), the top of unit $\mathrm{H}$ consists of light grey, friable, calcareous laminated sandstone. Between this disconformity and the K-T boundary is a $50-\mathrm{cm}$ thick interval of predominantly laminated dolomitic limestone here labelled Unit Ia.

\section{Unit Ia: $794.60 \mathrm{~m}$ to 794.10}

This 50 -cm-thick interval is between the disconformities at the top of the breccia and the K-T boundary. The interval consists predominantly of laminated micritic limestone, with microlayers or patches of anhedral dolomite crystals and a 5-cm-thick coarse dolomite layer at the base. The micritic limestone indicates deposition under low energy quiet water deposition, whereas the dolomite formed by diagenetic replacement of the precursor limestone with the original laminated texture still 

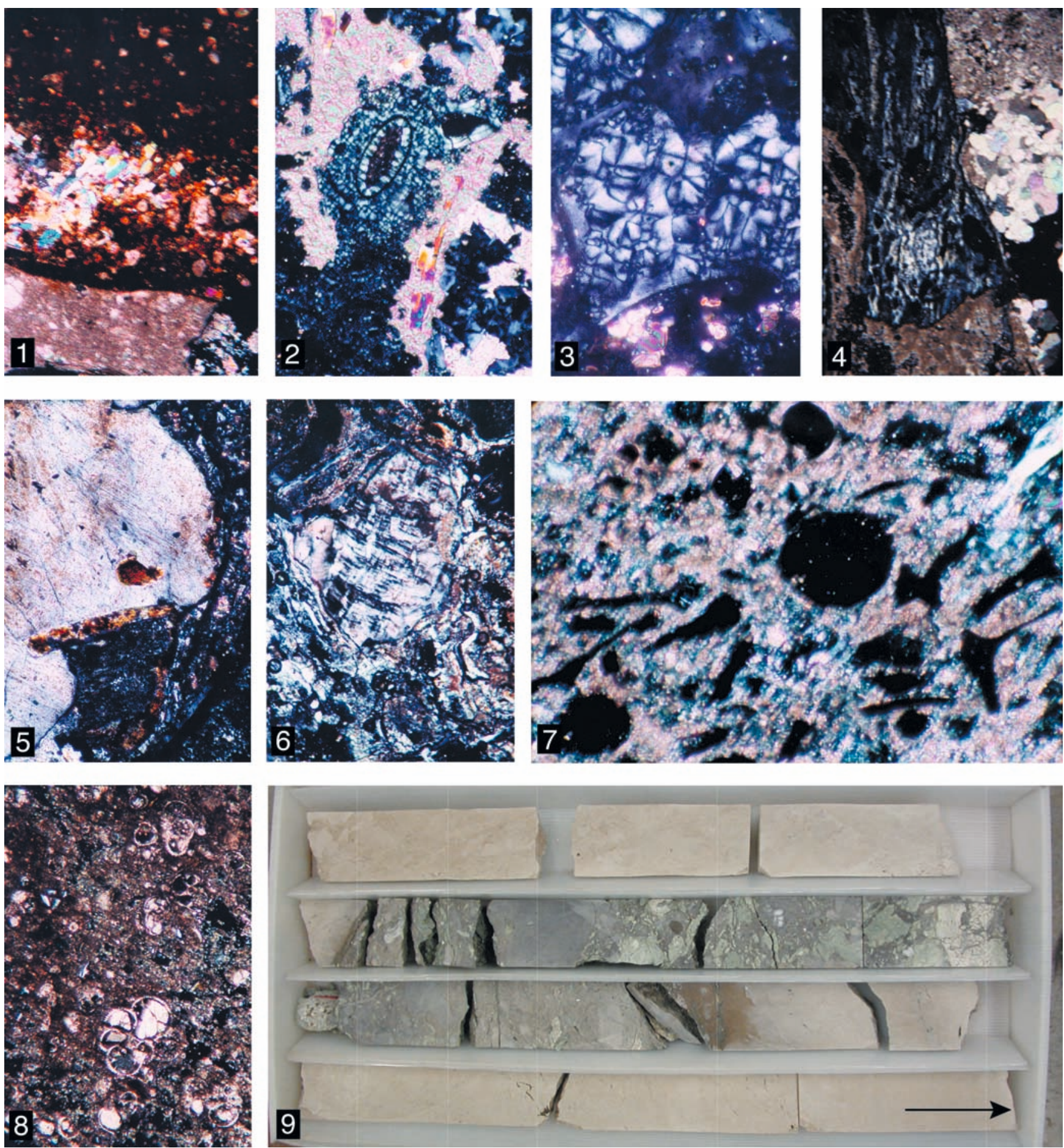

visible. In the lower $20 \mathrm{~cm}$ of this unit are three thin $(1 \mathrm{~cm})$ layers with oblique bedding, which may have formed from weak bottom currents by slightly agitated waters. However, the absence of grain size changes suggests that this may be diagenetic feature or related to settling (Fig. 6).

Five thin green clayey microclast layers are embedded in the laminated limestones at 794.43, 794.34-794.35, $794.24,794.19$ and $794.11 \mathrm{~m}$ of which the latter marks the K-T boundary and a significant hiatus. The insoluble residues of these intervals reveal that the microclasts are of glauconite origin and/or have in situ glauconite coating. Environmental scanning electron microscope and XRD analyses of the clasts and green clay reveal a glauconite XRD pattern characterised by a diffraction peak localised between $10 \AA$ and $12 \AA$ (Odin 1975) (Fig. 7). No altered glass is present. For comparison, we have analyzed four samples from the breccia at depths of 
Fig. 51 Dark dolostone and limestone (left) with injection vein (clastic "dyke") filled with authigenic anhydrite, gypsum, dolomite, K-feldspar, jarosite and bitumen/kerolite. Photomicrograph, thin section, crossed nicols. Sample 1867/1,398.5 m; width $=0.6 \mathrm{~mm} ; 2$ Suevite breccia dykes. Silicate melt fragment wholly devitrified, with microspherulitic texture, bordered by high-temperature secondary crystallised calcite, anhydrite and K-feldspar. Photomicrograph, thin section, crossed nicols. Sample 1889/915.5 m; width $=0.6 \mathrm{~mm} ; 3$ Suevite breccia dyke. Microspherulitic texture, devitrified melt clast. Photomicrograph, thin section, crossed nicols, sample $1889 / 915.5 \mathrm{~m}$; width $=0.6 \mathrm{~mm}$; 4 Suevite breccia dykes. Melt shard with fluidal texture, partially devitrified, and fine dolomitic limestone thermally metamorphosed to coarse crystalline marble. Thin section, crossed nicols. Sample 1889/915.5 m; width $=2.8 \mathrm{~mm} ; 5$ Suevite impact breccia. Large crystalloclast of shocked quartz with two sets of PDF's (angle of $40^{\circ}$ ) in a silicate melt, cryptocrystalline groundmass. Thin section, crossed polars. Sample $1899 / 801 \mathrm{~m}$; width $=0.6 \mathrm{~mm}$; 6 Suevite impact breccia. Shocked microcline xenocryst with PDF's with silicate matrix and minor carbonate components. Thin section, crossed nicols. Sample $1895 / 895 \mathrm{~m}$, width $=0.6 \mathrm{~mm} ; 7$ Dacitic-andesitic vitrocrystalloclastic tuff layer at $780 \mathrm{~m}$ depth. Note ground mass of calcite and glass shards. Thin section, crossed nicols. Sample 968/779 m width $=2.0 \mathrm{~mm} ; 8$ Micritic limestone containing foraminifers (Planorotaloides compressa, Subbotina sp.) and dispersed daciticandesitic vitrocrystalloclastic tuff material. In a groundmass of calcite and glass shards occur sporadically quartz, plagioclase, biotite and $\mathrm{FeCrNi}$ tiny particles. Thin section, crossed nicols. Sample $968 / 779 \mathrm{~m}$ width $=1.0 \mathrm{~mm}$; 9 Suevitic breccia dyke, approximately $30 \mathrm{~cm}$ thick, with thermal alteration of adjacent limestone to marble (Core Box 269, between 915 and $917 \mathrm{~m}$ depth)

827.81, 851.02, 861.74 and $876.37 \mathrm{~m}$. XRD analysis of these intervals show the presence of Cheto smectite, which is characteristic of altered glass (Fig. 7) Glauconite forms at the sediment-water interface with very slow detritus accumulation. The five microclast layers therefore reveal long pauses in the overall quiet depositional environment with reduced sedimentation and the formation of glauconite followed by sediment winnowing, clast generation and small-scale transport by minor current activity.

Sediment deposition in a normal low energy marine environment over an extended time period is also indicated by the burrowed glauconitic horizons and the heavily bioturbated (Thalassinoides) uppermost $10 \mathrm{~cm}$ of this 50 -cm-thick interval.

Microfossils within this 50 -cm-thick interval also indicate deposition in a normal marine environment over a long time period and characteristic late Maastrichtian assemblages provide critical age control. Examination of thin sections reveals the laminated micritic intervals to be rich in late Maastrichtian planktic foraminifera, although they are invariably recrystallised and poorly preserved in micritic limestones. The recrystallization process, however, retained the species morphology and the lighter colored shell calcite with respect to the surrounding micrite. A number of species have been identified (e.g., Rugoglobigerina, Plummerita hantkeninoides, Globotruncana, Heterohelix, Hedbergella and Globigerinelloides (Fig. 4, 13-19) and date this interval as latest Maastrichtian $P$. hantkeninoides zone (zone CF1, 65.3-65.0 Ma).

\section{Unit Ib}

Upsection, unit Ib consists of homogenous and mottled white to light grey micritic limestones (planktic foraminiferal wackestones), which are only slightly dolomitic. Mottled sediments and bioturbation by chondrites and Thalassinoides are common, whereas flaser-bedded intervals containing slightly coarser grains are rare. The first Danian planktic foraminifera and abundant Thoracosphaera are present in a calcareous mudstone $2 \mathrm{~cm}$ above the glauconite disconformity and hiatus. In this interval, rare miliolids and the early Danian planktic foraminifera P. eugubina are observed. In the $5 \mathrm{~cm}$ above this interval (samples 4-6; 794.05-794.09) a diverse early Danian assemblage is observed, including $P$. eugubina, Guembelitria cretacea, $G$. daubjergensis, $G$. pentagona, $W$. hornerstownensis, C. midwayensis, P. pseudobulloides and S. triloculinoides (Fig. 4, 9-12). This indicates that the earliest Paleocene samples are of upper $P$. eugubina zone age, or Pla(2). The absence of $P$. eugubina in assemblages upsection (samples 3 to 1; between 793.98-793.87 m), but abundance of large and well-developed $S$. triloculinoides, $P$. pseudobulloides and Morozovella inconstans indicate the upper part of zone Plc(1) (Fig. 4 6, 7). Benthic foraminifers and ostracods are commonly present. Upsection, at about $789.7 \mathrm{~m}$, sample 957 contains rare $M$. trinidadensis, along with numerous shallow benthic foraminifers, and may be located close to the $\mathrm{P} 1 \mathrm{c} / \mathrm{d}$ contact. Only $50 \mathrm{~cm}$ above, sample $958(789.2 \mathrm{~m})$ is rich in $M$. praecursoria, G. compressa, $M$. trinidadensis, $P$. pseudobulloides and $S$. triloculinoides and indicates the presence of Zone P2 of the middle Paleocene. Zone P3a planktic foraminiferal assemblages first appear in sample $959(788.2 \mathrm{~m})$, as indicated by abundant and welldeveloped $M$. praecursoria, M. uncinata, Planorotalites chapmani?, M. angulata and S. velascoensis (Fig. 4, 15). The diverse and abundant early Danian to middle Paleocene planktic foraminiferal assemblages in a $10-\mathrm{m}$ interval with zones $\mathrm{P} 1 \mathrm{a}-\mathrm{b}, \mathrm{P} 1 \mathrm{~d}$ and $\mathrm{P} 2$ represented by less than $1 \mathrm{~m}$ of sediment, indicate very reduced sedimentation and major hiatuses.

The lowermost $50-100 \mathrm{~cm}$ of unit I reflect minor bottom current activity, as indicated by small-scale cross-bedded and flaser-bedded dolomitic limestone and two 1-cm-thick microconglomerates. Apart from these microconglomerate layers, there is no evidence of reworked clasts derived from the suevitic impact breccia unit $\mathrm{H}$. However, one glass fragment was observed in sample $10,5 \mathrm{~cm}$ below the $\mathrm{K} / \mathrm{T}$ boundary. Unit I is characterised by bioturbated biomicrite rich in planktic foraminifera, which suggest deposition occurred in a middle to outer neritic, quiet water environment (Fig. 3, 7; Fig. 4, 1-19). A lower sea level is suggested for sample 956 (at $789.9 \mathrm{~m}$ depth) near the $\mathrm{P} 1 \mathrm{c} / \mathrm{d}$ contact, by increased abundance of benthic faunal elements (e.g., benthic foraminifers, ostracods, bivalves). A sea level lowstand at this stratigraphic position has been documented in the South Petén basin of Guatemala in southern Yucatan (Stinnesbeck et al. 1997). 


\section{Unit K; 784-774.65 m}

Unit $\mathrm{K}$ consists of hemipelagic marly limestones (planktic foraminiferal wackestones) intercalated with conglomerate layers that range from a few centimetres to $3 \mathrm{~m}$ thick. Planktic foraminiferal assemblages in the marly limestones are rich in $M$. praecursoria, $M$. angulata and S. velascoensis, indicating a P3a age for most of unit $\mathrm{K}$ and deposition in an outer to middle shelf environment (Fig. 4, 1-5). Only the uppermost sample 972 $(775.0 \mathrm{~m})$ contains a planktic foraminiferal assemblage indicative of Zone P3b (e.g., S. velascoensis, P. chapmani, $M$. angulata, A. primitiva). Conglomerate clasts are subrounded to rounded, up to $5 \mathrm{~cm}$ in diameter, and consist of bioclastic and micritic limestones. Lithologies include mudstones, and diverse bioclastic grainstones containing peloids, benthic foraminifers, echinoderms, gastropods, bryozoans, bivalves, rhodophytes and cyanophycean algae (Fig. 3, 10-13). These clasts are clearly derived from shallow carbonate platform envi- ronments and indicate transport into deeper water, probably by debris flows. For some conglomerate layers, size-graded lithologies were identified which also suggest an origin as sediment gravity flows.

Occasional clasts of planktic foraminiferal wackestone in the same conglomerate layers suggest rip-up and reworking from lithified hemipelagic lithologies. In some of these clasts (e.g., sample 964, at $784 \mathrm{~m}$ depth), $S$. triloculinoides, $M$. inconstans, $P$. pseudobulloides and P. compressa are present (Fig. 3, 8, 9). These species are of early Danian P1c age and indicate that older Paleocene sediments have been eroded and redeposited. No lithologies derived from the suevitic impact breccia (unit $\mathrm{H}$ ) were observed. In some layers, clasts are floating in a matrix of marly limestone (planktic foraminiferal wackestone) (Fig. 3, 8), while other layers, especially in the upper part of unit $\mathrm{K}$, are clast-supported and indicate imbrication. Characteristic unit $\mathrm{K}$ lithologies continue above $774.65 \mathrm{~m}$, but were not analyzed in this study.
Fig. 6 Lithostratigraphic contact between the suevitic impact brecca (top of unit $H$ ) and overlying dolomitic limestones (unit I). The contact between these units is abrupt, likely erosive, and represents a hiatus. Note that the suevitic sediment consists of crossbedded friable sand layers and was reworked by ocean water. Dolomitic limestones show small-scale cross and flaser bedding and bioturbated mottled intervals. Two 1-cmthick microconglomerate layers are present. There is no reworked debris of carbonate platform origin. Early Danian sediments above the $\mathrm{K} / \mathrm{T}$ boundary indicate an upper $P$. eugubina zone, or zone P1a(2) age, and mark an early Danian hiatus with zones $\mathrm{P} 0$ and $\mathrm{P} 1 \mathrm{a}(1)$ missing

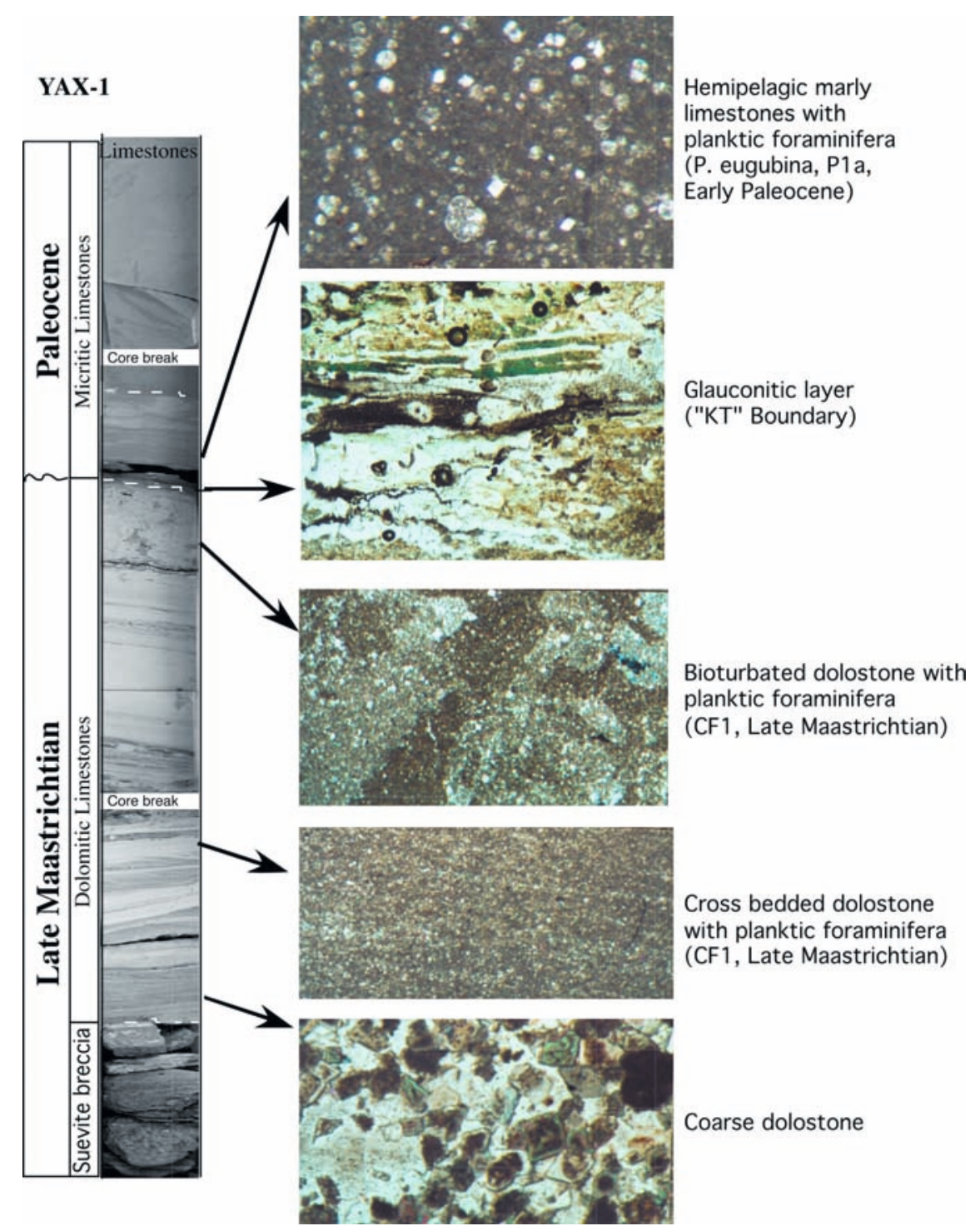



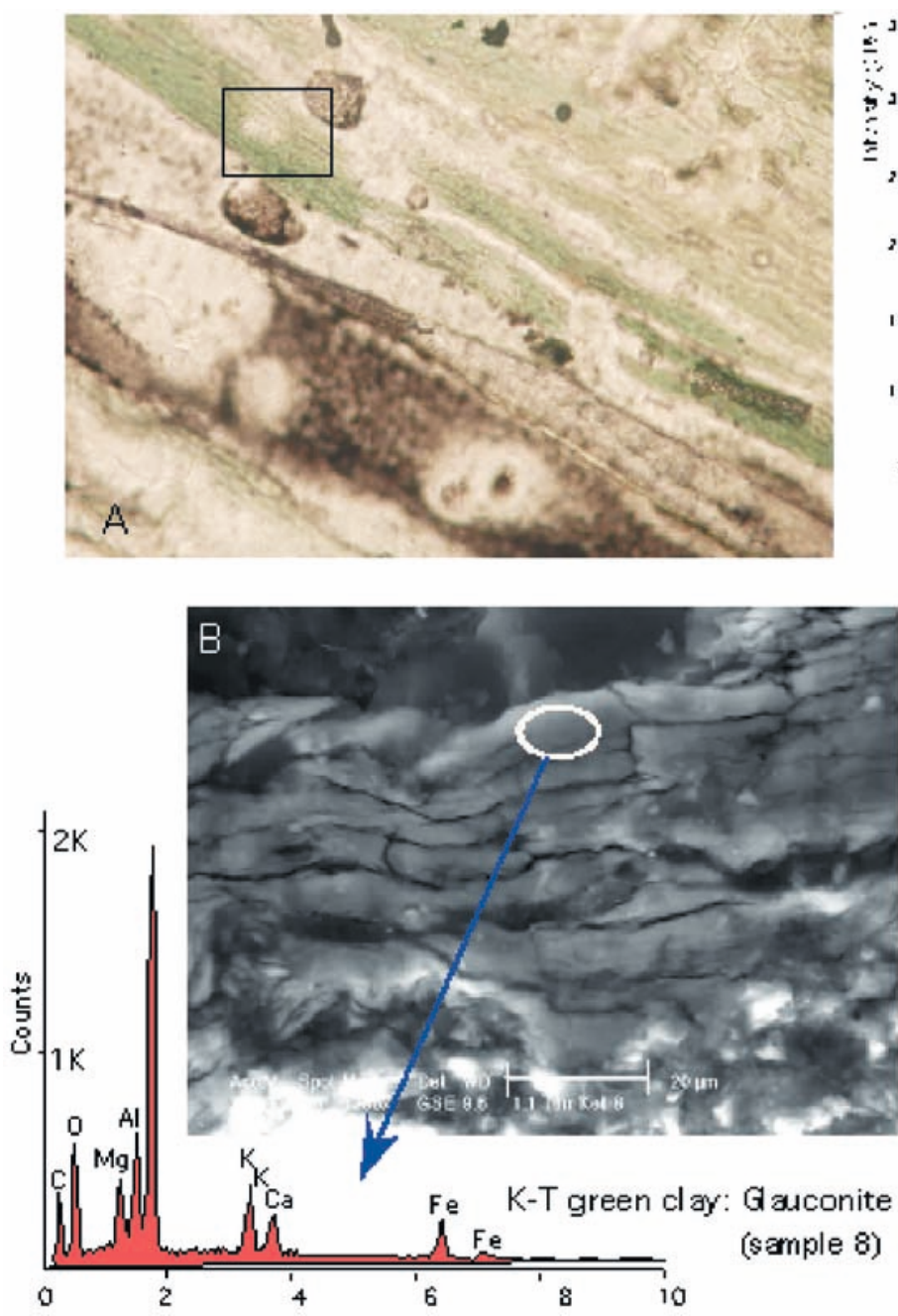

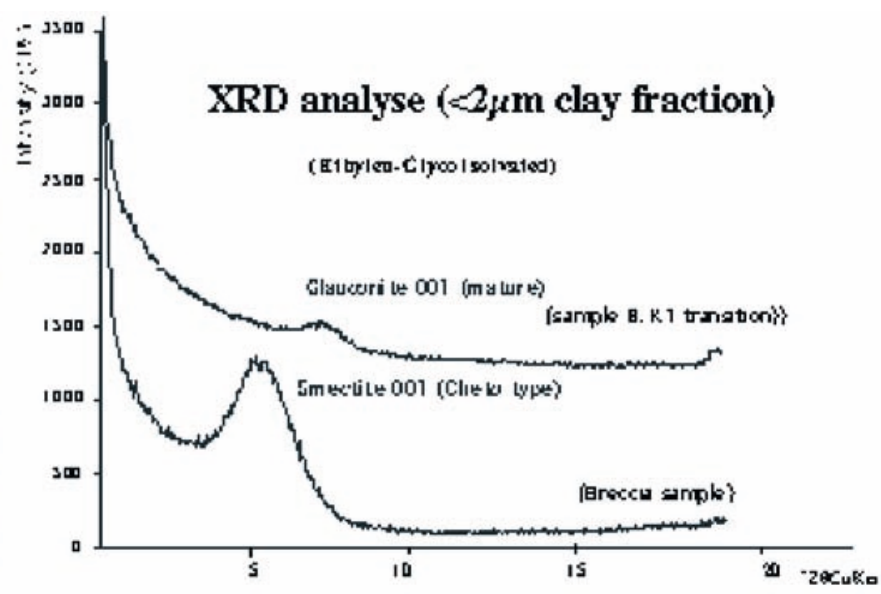

Energy Dispersive X-Ray Spectra (EDX):

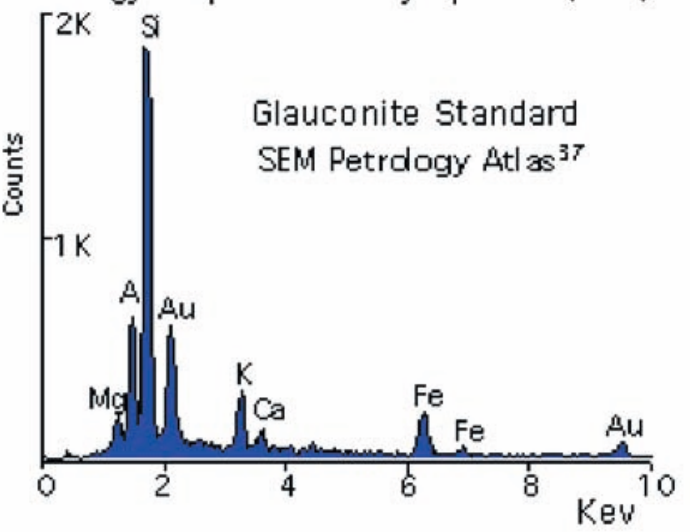

Fig. 7 Top left: Thin section of green $\mathrm{K} / \mathrm{T}$ boundary clay-layer (sample 8, $794.19 \mathrm{~m}$ ) with insert marking of ESEM-EDX analyses. Top right: XRD diffractogram of this green clay indicating the presence of mature glauconite. In contrast, XRD analyses of impact breccia samples showing the presence of well crystallised smectite (Cheto type), a typical glass weathering product. Bottom left: ESEM micrograph of the green $\mathrm{K} / \mathrm{T}$ clay (sample 8) with EDX analysis that indicates a glauconitic composition. (Note that the $\mathrm{Cl}$ peak is due to the chlorhydric acid used in preparation of insoluble residue). Bottom right: the glauconite reference standard from the SEM Petrology Atlas is shown for comparison

Sediment deposition of unit K occurred in a shallow water proximal ramp setting with some influx from nearby shallow water and carbonate platform environments. Conglomerates of unit $\mathrm{K}$ appear to be of debrisflow and turbidite origin and are dominated by skeletal limestones of shallow water origin. There are no terrigenous or impact-derived clastic components present.

Volcanic tuff layer in unit $\mathrm{K}$

At $780 \mathrm{~m}$ depth a light grey-coloured porous volcanic tuff of dacitic to andesitic composition is interlayered in the limestone sequence of unit $\mathrm{K}$. This layer is at least $1 \mathrm{~m}$ thick. In addition to abundant calcite, dolomite and fossils (e.g., planktic foraminifera), shards and small pumice fragments are present, with glass altered to analcime and other zeolites (documented optically and by XRD and EDX) (Fig. 5, 7, 8). Sporadic crystal fragments include surprisingly fresh plagioclase (oligoclase-labradorite; $30-65 \%$ An) with zonal structures, twins and fluid inclusions, as well as fresh green-brown biotite and rare hornblende and quartz. The latter also show fluid inclusions. Euhedral crystals of zircon, rutile, monazite and apatite are also common accessory minerals. Minerals of hydrothermal and authigenic origin include abundant analcime and albite, adular, strontiobaryte, sepiolite, smectite and pyrite. Analcime characterizes tuffs of andesitic composition and is also present in other volcanogenic rocks (Hay 1977; Iijima 1980; Utada 2001). The tuff layer may be related to volcanism along fracture zones on the flanks of the Chicxulub crater. This is the first evidence for volcanism of Paleogene age (zone P3a) on the Yucatan peninsula.

Special attention needs to be paid to an unexpected component of the glassy - analcime tuff matrix. We identified numerous metallic fragments rich in $\mathrm{Fe}, \mathrm{Cr}$ and $\mathrm{Ni}$ with minor $\mathrm{Si}, \mathrm{Mg}, \mathrm{Ca}$ and $\mathrm{Al}$. Microscopic and SEM-EDX examination indicates that particles are be- 
tween 2-20 $\mu \mathrm{m}$ in diameter, isometric, subidiomorphic and sometimes forming platy crystals or rose aggregates. Semiquantitative analysis (6 samples) reveals a composition (wt\%) of Fe (total) 57.68-64.32, Cr 16.71-20.03, Ni 7.97-10.53, Mn 0.70-1.75, Al 0.84-3.36, Mg 0.291.12 and $\mathrm{Si} 2.49-3.43$. The high contents of $\mathrm{Cr}$ and $\mathrm{Ni}$ and systematic $2: 1 \mathrm{Cr} / \mathrm{Ni}$ ratio are highly unusual for crustal rocks but agree with published data for Ni-rich materials or $\mathrm{Fe}-\mathrm{Cr}-\mathrm{Ni}$ alloy of impact origin (e.g., El Goresy and Chao 1976; Bohor et al. 1986; Robin et al. 1991; Kyte and Smit 1986; Deer et al. 1993). However, with no other supporting evidence at hand for chondritic bolide origin, these strange minerals in the volcanic tuff of zone P3a remain enigmatic.

\section{Discussion}

Pre-impact units at Yaxcopoil-1

\section{Depositional environment}

Diagenetic dolomitization of the Cretaceous limestone sequence in the Yaxcopoil-1 core often disguises original carbonate microfacies, though they can generally still be recognised. Lithologies of units $\mathrm{A}, \mathrm{C}, \mathrm{D}$ and $\mathrm{F}$ are dominated by dolomites and anhydrites and indicate restricted interior carbonate platform environments (Fig. 2). Dolomites were likely deposited in very shallow subtidal to intertidal environments, as also indicated by the presence of mudstone lithologies, anhydrite nodules, laminated dolomite of likely stromatolitic origin, and the generally low abundance of megafossils (only rare bivalve fragments). Miliolids are often the only benthic foraminifera recovered from these intervals and they are very rare. Alternating sequences of anhydrite and dolomite and massive anhydrite units are interpreted to indicate deposition in sabkha environments.

Lithologies in units $E$ and $G$ are characterised by muddy limestones, peloidal mudstones and grainstones, bioclastic grainstones and packstones with occasional bivalves and common to abundant benthic foraminifera, principally miliolids and lenticulinids. Depositional conditions are thus less restricted than in units C, D and $\mathrm{F}$ and appear to reflect lagoonal carbonate platform or even shallow open marine environments (Fig. 2).

Only unit B was not deposited in a carbonate platform environment (Fig. 2). The abundance of planktonic foraminifera, pelagic crinoids and calcispheres in this unit indicates deposition occurred in an open marine shelf environment. Overall, the anhydrite component in Yaxcopoil-1 is about $25 \%$ of the section (157 of $>615 \mathrm{~m}$ ), less than expected from published records (e.g., Lopez Ramos 1973, 1975).

\section{Origin of breccia}

Stratiform breccia intervals are repeatedly intercalated in the Cretaceous pre-impact sequence, principally in units $\mathrm{A}, \mathrm{D}$ and $\mathrm{F}$, which characterize restricted inner platform environments. There are only minor breccia intervals in units $E$ and $G$, which represent lagoonal environments, and no breccia was recognised in the open marine sediments of unit B. This preference for restricted intertidal facies and the absence of external clast lithologies and exotic input, such as glass spherules, altered glass shards, microspherules of impact origin, shocked minerals, basement clasts, or glass weathering products (e.g., well-crystallised smectite of Cheto type, see Keller et al. 2003a, 2003b) do not favour an impact origin. Rather, these stratiform breccia layers are of intraformational origin, as also supported by conformable and sometimes gradational contacts to under- and overlying non-brecciated units. In restricted carbonate platform environments, breccias typically originate as a result of dissolution of evaporites and carbonates. We therefore suggest the thicker breccia layers are collapse breccias related to these processes. Thinner breccia layers often contain "floating" isolated clasts and appear to reflect penecontemporaneous disturbances or rip-up of semi-lithified clasts and redeposition.

A third type of breccia is of diagenetic origin and formed by diagenetic alteration of limestone and gypsum to dolomite with chicken-wire textures. Additional structural shearing and brecciation may have occurred as suggested by Kenkmann et al. (2003), but the overall stratification appears intact. We found no evidence for a breccia origin due to impact-generated seismicity (i.e. instant shaking, major shearing and displacement of different blocks).

\section{Dykes}

Smit et al. (2002), Wittmann et al. (2003) and Kenkmann et al. (2003) reported on numerous pseudotachylite veins and dykes of suevite and melt rock in the pre-impact sequence of Yaxcopoil-1. However, examinations of the cores revealed that dykes are extremely rare in the sequence and, in fact, only two injection veins (10 and $30 \mathrm{~cm}$ thick) were recognised in unit $\mathrm{C}$ at depths of $1,398.5$ and $1,348 \mathrm{~m}$, and two suevitic breccia dykes close to the contact between units $\mathrm{G}$ and $\mathrm{H}$ (915 and 909 m; Fig. 2; Fig. 5, 9). The injection veins in unit $\mathrm{C}$ (sample 1867, box 417; sample 1868, box 399) consist of black fine-grained bituminous dolomite with intraclasts of anhyrite, calcite, pyrite and clay minerals (Fig. 5, 1). They are flanked by recrystallised calcite microbreccia with halite and gypsum neomorphs and by dark crystalline dolomite. Subsequent hydrothermal activity and alteration is indicated by K-feldspar, fluorite, pyrite, jarosite, anhydrite, gypsum, halite and clay minerals (smectite, mixed layer, illite), accompanied by mobilised bitumen localised along shear zones in the dolomite. These injection veins formed by the forcing of sediment and hydrothermal minerals into cracks or shear zones in pre-existing dolomite with minor anhydrite and calcite.

The upper part of unit $\mathrm{G}$ between 916 and $909 \mathrm{~m}$ contains 2 suevite breccia dykes that are up to $30 \mathrm{~cm}$ 
thick (Fig. 2; Fig. 5, 9). For instance, sample 1889 at a depth of $915.5 \mathrm{~m}$ (box 234) consists of recrystallised anhydrite and calcite. High temperature origin is indicated by recrystallised and altered "vibrated" microspherules, vitroclasts (shards) and melt rock fragments (Fig. 5, 2-4). Melt shards are devitrified and intensively altered to well-crystallised smectite, calcite, K-feldspar (adular) and zeolites. Quartz and feldspars with planar deformation lamellae are also abundant in this sample and indicate shock deformation and an impact origin (Fig. 5, 5, 6).

The intrusion of these suevite dykes disrupted sedimentation and caused thermal alteration of the adjacent dolomitic limestones to marble The contact between the two lithologies is figured in Fig. 5, 9. Despite the physical disruption and tilting of sediments, the stratigraphic sequence appears to be in place, as indicated by the continuity of sedimentation above and below the suevite breccia dykes.

\section{Late Cenomanian R. cushmani zone marker unit}

The stratigraphy of the northern Yucatan Peninsula is primarily known from records of the Petróleos Mexicanos (Pemex) exploration wells (e.g., López Ramos 1973, 1975; Marshall 1974; Meyerhoff et al. 1994), which recovered Cretaceous carbonates and anhydrites of carbonate platform origin. Only Ward et al. (1995) noted deeper-subtidal limestones and marls in samples of wells Y1, Y2, Y4 and Y5A and correlated these to the Bonarelli event (OAE2) near the Cenomanian-Turonian boundary (Fig. 8). Yaxcopoil-1 confirms this observation. The bituminous and finely laminated marly limestone of unit B is rich in planktic foraminifera of latest Cenomanian age (e.g., Whiteinella archaeocretaceas, $W$. baltica, Rotalipora cushmanni, R. greenhornensis, Hedbergella spp.) and pelagic crinoids (? Roveacrinidae), which indicates deposition occurred in a low-oxygen environment under open marine shelf to basin conditions (Fig. 3, 1, 5; Fig. 4, 20-26). Coeval pelagic sediments have also been reported from the southwestern and southern margin of the Yucatan Block by Schafhauser et al. (2004) who documented micritic limestones of Cenomanian age for the Punta Gorda area of southern Belize. Fourcade et al. (1999) described strikingly similar lithologies and microfaunas from the B member (unit 9) of the Coban Formation in the southern Petén basin in Guatemala. The OAE2 event thus appears to be well represented throughout the Yucatan platform and forms a valuable marker horizon (Fig. 8).

\section{Normal vs. chaotic sedimentation of pre-impact units}

The sequence of Cretaceous units A to G appears to be in place, little disturbed and more or less autochthonous, as indicated by correlatable horizons of similar stratigraphic levels in Pemex wells across the region (Fig. 8). There is no evidence for major disruption of sediments, chaotic changes in the lithology or overturned or deeply dipping megablocks, as would be expected from major seismic disruption as a result of a large Chicxulub impact. Moreover, no major mechanical fragmentation or shock alteration appears to be present and breccia units in the Cretaceous pre-impact sequence appear to be of intraformational rather than impact-generated origin.

Even the abrupt lithostratigraphic contact between pelagic marly limestones of unit B and dolomites with clear carbonate platform character of unit $\mathrm{C}$ (at a depth of $1,452 \mathrm{~m}$ ) appears to be conformable as no major breccia of "tectonic" origin is present and the sediment dip is similar above and below. Fourcade et al. (1999) described a similarly abrupt contact between open marine Upper Cenomanian lime mudstones and overlying crystalline carbonate platform dolomites from an undisturbed sequence of the Coban Formation in the South Petén basin of Guatemala. At Yaxcopoil-1 a conformable, though not necessarily complete, stratigraphic contact appears to exist between units B and C.

The pre-impact sediments of Yaxcopoil-1 thus represent a parauthochtonous and normal stratigraphic sequence, comparable to Cretaceous platform sediments known from outside the Chicxulub crater in northern Yucatan (e.g., Ward et al. 1995), or the southern Yucatan block (Coban Fm., Campur Fm.; Stinnesbeck et al. 1997; Fourcade et al. 1999; Schafhauser et al. 2004). Units A to F can be roughly correlated with the Coban Formation of late early to late Cretaceous age, whereas the youngest unit $G$ represents a less restricted facies and may correlate with the Campur Formation, or with a rudist-bearing interval of Turonian age known from Pemex wells in northern Yucatan (Fig. 8; Unit E of Ward et al. 1995).

Correlation of Yaxcopoil-1 with other Yucatan Wells: implications for the Chicxulub impact crater

The Cretaceous sequence of Yaxcopoil-1 can be correlated with other wells in the area which penetrated up to $3.500 \mathrm{~m}$ of stratified Tertiary, Cretaceous and Jurassic sedimentary rocks consisting primarily of evaporites, dolomites and platform limestones (e.g., Ward et al. 1995; Fig. 2). Paleozoic metamorphic rocks were encountered at 2,418 $\mathrm{m}$ in well Y4 and at 3,202 $\mathrm{m}$ in well Y1 (Fig. 8). The only unusual lithologic unit present in all cores is the suevitic breccia. Three wells near the center of the crater, Chicxulub 1 (C-1), Sacapuc 1 (S-1) and Yucatan 6 (Y-6) (Fig. 8), penetrated impact melt rock underlying the breccia, but at Y-6 limestone and anhydrite were encountered underlying the melt rock (Fig. 8; Meyerhoff et al. 1994; Ward et al. 1995), though it can not be determined whether these sediments are normally stratified or represent chaotic blocks.

Yaxcopoil-1 is lithologically and stratigraphically comparable to the northern Yucatan PEMEX cores (Fig. 8). For instance, the thickness of post-Cenomanian sediments is similar to Ticul-1 (T-1) and Yucatan-2 
YAXCOPOIL -1: CORRELATION WITH THE NORTH YUCATAN WELLS

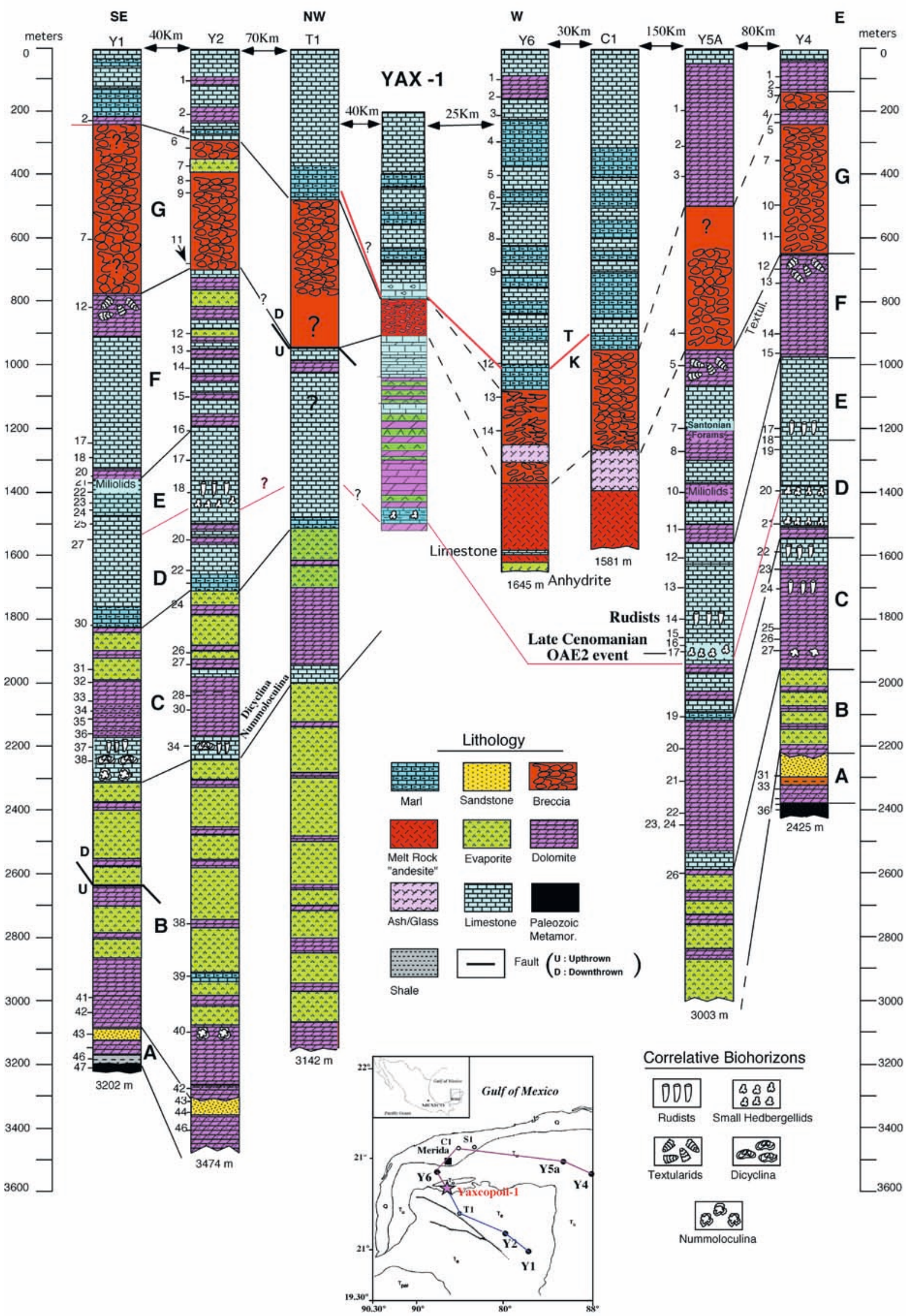


Fig. 8 Stratigraphic correlation of CSDP well Yaxcopoil-1 and PEMEX wells of the northern Yucatan Peninsula. Mesozoic are based on lithology, correlative fossil zones, and electric-log characteristics. (modified from Ward et al. 1995). Note that the hemipelagic marly limestone of Uppermost Cenomanian (R. cushmani zone) age forms an excellent marker horizon throughout most of Yucatan. The suevitic impact breccia can also be correlated regionally. This unit is only $100 \mathrm{~m}$ thick at Yaxcopoil-1, much less than in any other well in the area

(Y-2), the two wells closest to Yaxcopoil-1 (Figs. 1, 8). T-1 and Y-2 appear to be located outside the Chicxulub impact crater whereas Yaxcopoil-1 was probably drilled on the collapsed margin or terrace zone of the Chicxulub impact basin, or even inside the transient crater (Morgan et al. 2002; Dressler et al. 2003a, 2003b). However, several lines of evidence argue against a location of Yax1 within the transient crater cavity. Even a location in the crater terrace zone or collapsed margin of the Chicxulub crater is not unequivocally sustained for several reasons.

1. Correlatable units of late Cretaceous sediments are similar in thickness and in subsurface depths to coeval sediments which are unequivocally located outside the crater. This points to a normal stratigraphic sequence of Cretaceous sediments at Yax-1, rather than the presence of chaotic megablocks. For instance, the organic-rich limestone with the latest Cenomanian planktic foraminiferal assemblage (unit B; top R. cushmani zone, $94 \mathrm{Ma}$ ) forms a correlatable horizon in Yax-1, Y-2, Y-5a and Y-4 (Fig. 8).

2. The Cretaceous pre-impact sequence lacks evidence of exotic or mixed lithologies, major impact deformation features (e.g., mechanical fragmentation, microtectonism, ductile deformation), and thermal alteration. Organic matter (T.O.C. $>7 \%$ ) is abundant in units B and C. Rock-Eval data indicate that it is particularly well preserved, did not suffer from thermal alteration, and never passed temperatures of $80-120^{\circ} \mathrm{C}$. The high HI, low OI and Tmax of $425^{\circ} \mathrm{C}$ are indicative of relatively immature and well-preserved organic matter. The general presence of clay minerals such as palygorskite and soil-derived smectite in the sediments of almost every unit support this assessment (Kübler 1997; Srodon and Eberl 1987). Thus, no major impact-related disturbance of Cretaceous strata is observed at a distance of only $60 \mathrm{~km}$ from the crater center.

3 . There is no melt rock below the impact breccia and dykes are small and rare (Fig. 2). In over $600 \mathrm{~m}$ of pre-impact sediments, only 2 suevitic dykes at 909 and $916 \mathrm{~m}$ depths, and two possible thin injection veins (at 1,398.5 and 1,348 $\mathrm{m}$ ) of possible impact origin were detected. This suggests that Yax-1 is located at a considerable distance from ground zero.

4. The impact breccia unit $\mathrm{H}$ consists of only $100 \mathrm{~m}$ of polymict suevitic breccia, as compared with 300 to $500 \mathrm{~m}$ of the same breccia units in PEMEX and
UNAM wells in the crater vicinity (e.g., Ward et al. 1995; also Fig. 8). The reduced breccia thickness in Yax-1 is not the result of erosion, as indicated by the absence of erosional disconformities within the breccia and gradual upward-fining of clasts in the top $15 \mathrm{~m}$. Only the upper contact with the overlying dolomitic limestones (unit I) is marked by a hiatus (Fig. 6). This relatively thin suevitic breccia unit is inconsistent with the proposed location of Yax-1 in the crater-like depression or at the collapse margin, unless some complex tilting or block faulting is invoked.

5. The contact at Yaxcopoil-1 between the Cretaceous pre-impact sequence (unit $G$ ) and impact breccia unit $\mathrm{H}$ is at a depth of $894 \mathrm{~m}$ and thus similar to the depth of this contact observed in the nearby T-1 well (between $800-980 \mathrm{~m}$ ) located outside the Chicxulub crater (Fig. 8). The same contact is at a depth of $1,400 \mathrm{~m}$ in Y-6 (or even $1,600 \mathrm{~m}$ if the melt rock is included) and $1,300 \mathrm{~m}(>1,561 \mathrm{~m}$ including melt rock) at C-1, two wells located near the crater center (Fig. 8). A similar depositional relationship is recognised for the latest Cenomanian ( $R$. cushmani zone) pelagic limestone (unit B) which is located at depths of approximately $1,500 \mathrm{~m}$ at $\mathrm{Y}-2$ and $1,550 \mathrm{~m}$ at $\mathrm{Y}-1$ and thus at similar depths as at Yax-1 (between 1,495 and 1,452 m; Fig. 8). At T-1, this horizon has not yet been recognised. The similar stratigraphic position and thickness of lithologies point to the absence of major normal faults between these localities. However, major faults should be present if Yax-1 is located inside the crater trough and the Cretaceous sequence formed by allochthonous blocks.

These lithologic observations suggest two possible scenarios.

1. Yax-1 is located outside the transient crater cavity and perhaps even outside the crater terrace zone, which would indicate that the Chicxulub impact crater is significantly smaller than previously estimated. Given the location of Yax-1 at $60 \mathrm{~km}$ from the center of the Chicxulub impact crater, the diameter of this crater is likely $<120 \mathrm{~km}$. This scenario is supported by the lithological observations and consistent sediment unit thickness across Yucatan wells as discussed above.

2. The Cretaceous sequence of Yax-1 represents a single undisturbed megablock more than $600 \mathrm{~m}$ thick, which tilted and slid into the crater basin essentially intact. This megablock could still be part of the terrace zone, though in a horst-like elevation where it formed the upper end of a tilted block (Fig. 9). The reduced thickness of the suevite unit $\mathrm{H}$ could have resulted from this horst position and led to nondeposition or rapid erosion of a major portion of the suevite prior to deposition of the limestone unit G. A topographic high in the ocean could also explain the fragmentary record and reduced thickness of early 
Paleocene sediments, as well the complete absence of reworked suevitic breccia (unit $\mathrm{H}$ ). This scenario suffers from the fact that tectonic uplift is quite uncommon in the marginal parts of a big impact crater where normal faulting, collapse and downhill sliding prevail.

The K/T boundary at Yaxcopoil-1 and the age of the Chicxulub impact

\section{Age and depositional environment of strata above impact breccia}

Attribution of a K/T boundary age to the Chicxulub crater needs to be based on precise biostratigraphic dating of sediments overlying the impact breccia, and evaluation of their depositional mode. Such data is not available from previous Yucatan wells in and around the crater. In PEMEX holes Y-6 and Sacapuc-1 (S-1, Fig. 1), faunas of Paleocene age have been reported to overlie the Chicxulub breccia unit and contain planktic foraminiferal assemblages of Zone P2 (Praemurica uncinata,first appearance at $61.2 \mathrm{Ma}$ ) almost $4 \mathrm{Ma}$ after the $\mathrm{K} / \mathrm{T}$ boundary, and indicate a major hiatus (Marín et al. 1994; Sharpton et al. 1996). In PEMEX well C-1, on the other hand, Lopez Ramos (1973) reported abundant Upper Maastrichtian planktic foraminifera in marls, shales and limestones overlying the impact breccia. Based on electric log characteristics, Ward et al. (1995) correlated the unit to well S-1 and concluded that up to $18 \mathrm{~m}$ of undisturbed uppermost Maastrichtian marls overlie the impact breccia at that locality. These authors cautioned that a scenario declaring Chicxulub as the $\mathrm{K} / \mathrm{T}$ boundary impact crater was premature and not substantiated on the basis of biostratigraphic data. Our investigation of Yax-1 provides critical evidence to support a late Maastrichtian age for sediments overlying the impact breccia.

The micritic limestones (base of unit Ia) disconformably overlie reworked suevitic impact breccia at Yax-1 (top of unit H; Fig. 6). A second major erosive surface is recognised at $50 \mathrm{~cm}$ above the base of unit I where a 3-4 $\mathrm{mm}$ thick glauconitic clay layer marks the top of the dolomitic limestone and underlies a 5-cm-thick bioturbated dark muddy limestone that contains the first Tertiary planktic foraminifera indicative of the upper part of zone Pla (Figs. 6, 10). The mature glauconitic clay (Fig. 7) that characterizes this interval requires at least $100 \mathrm{ky}$ to form (Chamley 1989) and indicates non-deposition and a hiatus. Thus, major erosional events mark both the post-impact event and the $\mathrm{K} / \mathrm{T}$ boundary.

The 50 -cm-thick dolomitic limestone that is bracketed by these two erosion events contain diverse late Maastrichtian planktic foraminiferal assemblages (Globotruncana, Heterohelix, Rugoglobigerina, Hedbergella and Globigerinelloides) characteristic of zone CF1 (Plummerita hantkeninoides) (Fig. 4) that spans the last $300 \mathrm{ky}$ of the Cretaceous (Pardo et al. 1996; Keller et al. 2003a; Fig. 10). The presence of deeper dwelling globotruncanids and middle shelf benthic foraminifera (e.g., Tristix sp.) indicates an open marine environment of at least $100 \mathrm{~m}$ water depth.

The very existence of these foraminifera has been questioned by Smit (2004a, 2004b; Smit et al. 2004) who claims that these images are "demonstrably misidentified dolomite rhombs posing for foraminiferal chambers" Smit (1994b). It can easily be demonstrated that the dolomite rhombs Smit considers as imposters or pseudomorphs of foraminiferal species (see Smit 2004a) are not foraminifera, and that the foraminifera illustrated in Figs. 11, 12 are not dolomite rhombs. In Fig. 11 we show four species images in two dimensions from thin sections of the Yax-1 core and compare each with the pristine $3 \mathrm{D}$ image of the same species. In each of the Yax-1 2D and pristine 3D images the number of chambers, chamber arrangement and overall morphology are essentially the same and can be clearly identified as the same species. There is clearly no comparison of these images with the dolomite rhombs that Jan Smit claims are posing for foraminifera. The fact that these late Maastrichtian zone $\mathrm{CF} 1$ assemblages are present in the $50 \mathrm{~cm}$ interval between the top of the impact breccia and the K-T boundary indicates that the Chicxulub impact predates the K-T mass extinction by about 300,000 years.

The faunal assemblages indicate in situ deposition, rather than reworking by backwash after the impact.

Fig. 9 Scenario interpreting the location of Yaxcopoil-1 as part of the terrace zone of the Chicxulub crater. Note that in this scenario the Cretaceous sequence represents a single megablock $>600 \mathrm{~m}$ thick, located on the upper end of a tilted horst

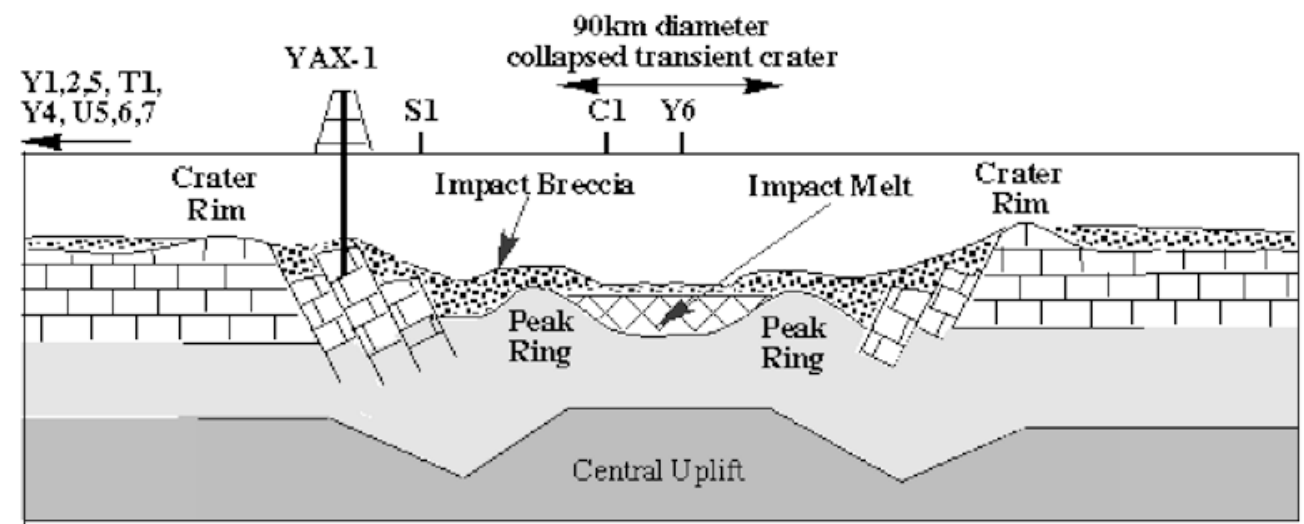




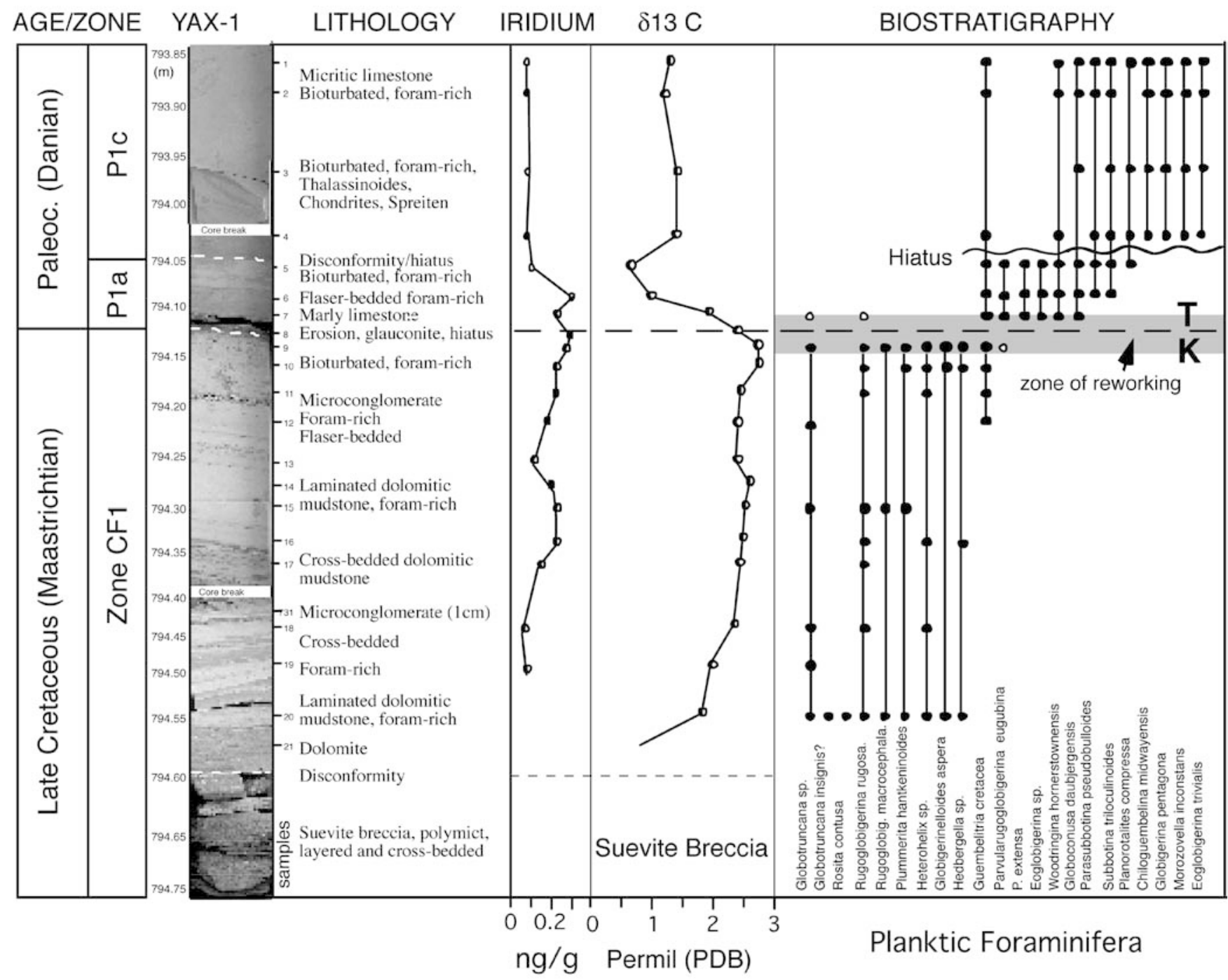

Fig. 10 Litho-, bio- and chemostratigraphy (Iridium, $\delta^{13} \mathrm{C}$ ) of the $\mathrm{K} / \mathrm{T}$ boundary transition at Yaxcopoil-1. Note that $50 \mathrm{~cm}$ of dolomitic limestones overlying the suevitic impact breccia were deposited in situ, during zone CF1 of the latest Maastrichtian. Deposition of the suevite thus occurred 250-300 ky prior to the K/T boundary. The $\mathrm{K} / \mathrm{T}$ boundary is incomplete and characterised by the juxtaposition of P1a(2) and latest Maastrichtian CF1 planktic foraminiferal assemblages. About $250 \mathrm{ky}$ are missing. A hiatus is independently suggested by the presence of mature glauconite and the absence of a major Ir anomaly. Another hiatus was detected $6 \mathrm{~cm}$ upsection, where zones P1a (2) and P1c are juxtaposed

This interpretation is supported by (1) the presence of both robust and fragile elements and large and small specimens indicating a non-sorted faunal character. (2) Hemipelagic faunal assemblages which contain no faunal mix from shallow waters. (3) Lime mudstone lithologies that indicate quiet water without evidence for grain size gradation and only occasional current activity (Fig. 6). (4) An abrupt contact and absence of gradational lithologies between the suevite and overlying dolomitic limestone. (5) The virtual absence of suevite glass or breccia clasts, which suggests a major hiatus and no reworking of the underlying breccia. (6) The absence of reworked debris of carbonate platform origin, such as shallow water limestones, dolomites or anhydrites from sediments underlying the impact breccia, which would have been the source for reworking and transport. (7) The absence of pelagic sediments with late Maastrichtian planktic foraminiferal assemblages below the suevite unit at Yax-1, or in any other Yucatan core (Ward et al. 1995; Sharpton et al. 1996).

\section{The K/T boundary at Yaxcopoil-1}

The $\mathrm{K} / \mathrm{T}$ boundary is recognised at $50 \mathrm{~cm}$ above the top of the impact brecia at the base of a $2 \mathrm{~cm}$ thick dark green-grey clay that contains mature glauconite. This clay layer disconformably overlies a bioturbated dark grey marly limestone with an impoverished latest Maastrichtian planktic foraminiferal assemblage and burrows infilled with light grey early Danian sediments (Figs. 6,9). The $6 \mathrm{~cm}$ of strata overlying the glauconite layer contain a diverse early Danian planktic foraminiferal assemblage indicative of the upper part of the P. eugubina zone or Pla(2) (e.g., well-developed Para- 


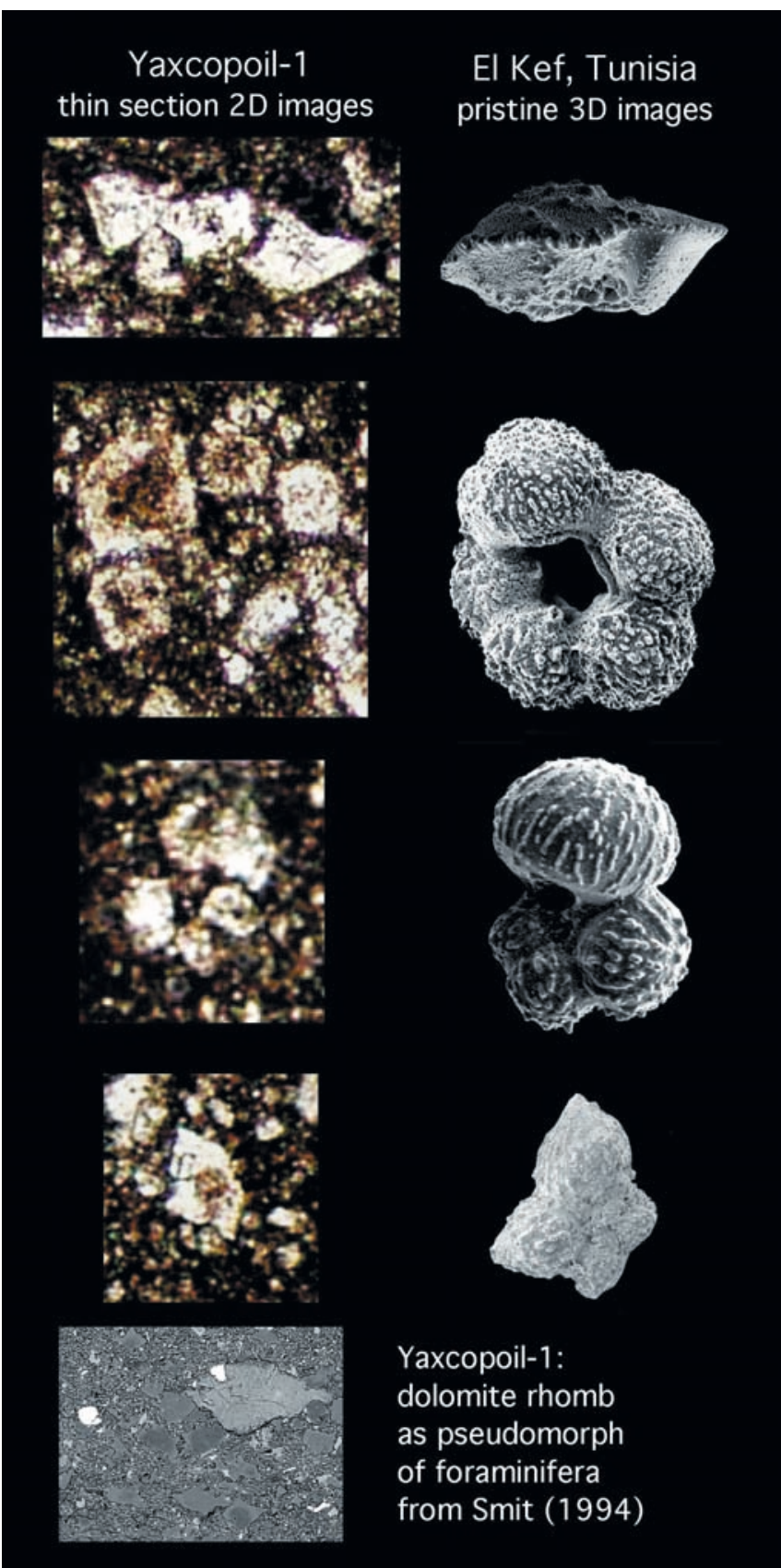

Fig. 11 Thin section images of Yax-1 foraminifera in 2D compared with pristine 3D images of the same species taken from the El Kef section of Tunisia. Note that the number and shape of chambers, the chamber arrangement and the overall morphology of the Yax-1 images are the same as for the pristine species and clearly show that they are foraminifera and not dolomite rhombs (shown at the bottom) as claimed by Jan Smit 2004a, 2004b; Smit et al. 2004. The species are from top to bottom: Globotruncana insignis, Rugoglobigerina rugosa, $R$. macrocephala, Plummerita hantkeninoides

subbotina pseudobulloides, Subbotina triloculinoides, $P$. eugubina). Another hiatus was identified at $6 \mathrm{~cm}$ above the $\mathrm{K} / \mathrm{T}$ boundary and marks an abrupt change in the species assemblage to larger size, the absence of $P$. eugubina and presence of Morozovella inconstans (Fig. 10). This assemblage is indicative of the upper part of zone Plc or subzone P1c(2).

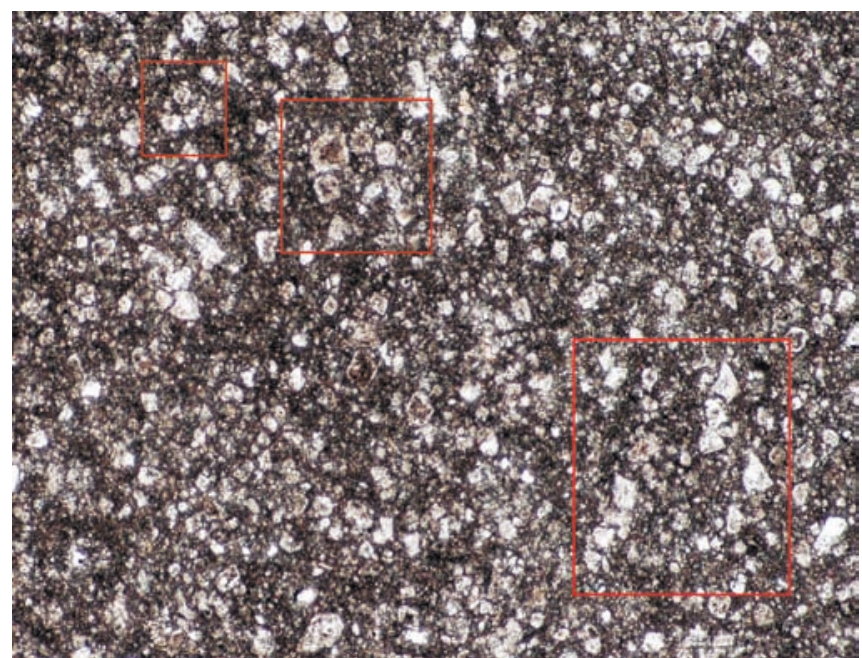

Fig. 12 Thin section photograph of sample Yax-1 20 from the interval at $794.55 \mathrm{~m}$. Note the abundance of planktic foraminifera some of which are highlighted. This assemblages includes large and small, fragile and robust species, which indicates in situ deposition in a normal marine environment

The juxtaposition of P1a(2) and late Maastrichtian zone $\mathrm{CF} 1$ assemblages indicates that a $\mathrm{K} / \mathrm{T}$ boundary hiatus spans the basal Danian zone P0 and subzone P1a(1), or about $250 \mathrm{ky}$ of the Danian and probably part of the uppermost Maastrichtian zone CF1. A prominent hiatus is independently recognised by the mature glauconite, the lithological change from light grey dolomitic lime mudstone to dark green-grey bioturbated lime mudstone, and by the absence of a major PGE anomaly at the K/T boundary (Fig. 10). Only a minor iridium enrichment of $0.30 \mathrm{ng} / \mathrm{g}$ is observed in the dark grey marly limestone overlying the $\mathrm{K} / \mathrm{T}$ boundary hiatus. Below the $\mathrm{K} / \mathrm{T}$ boundary hiatus $\mathrm{Ir}$ values reach $0.22 \mathrm{ng} / \mathrm{g}$ and decrease downsection. No significant Ir values were detected in dolomitic limestones directly overlying the suevitic breccia (0.06-0.08 ng/g Ir).

Stable isotopes show relatively constant late Maastrichtian $\delta^{13} \mathrm{C}$ values $(\sim 2.4 \%)$ in the dolomitic lime mudstone overlying the suevitic breccia up to the $\mathrm{K} / \mathrm{T}$ boundary (Fig. 10). Lower values are only observed in the dolomite above the breccia and indicate diagenetic alteration. At the $\mathrm{K} / \mathrm{T}$ boundary, the negative excursion of about $2 \%$ in $\delta^{13} \mathrm{C}$ is characteristic of $\mathrm{K}-\mathrm{T}$ transitions worldwide (e.g., Romein and Smit 1981; Hsü et al. 1982; Schackleton and Hall 1984; Keller et al. 1998; Sial et al. 2001; Keller et al. 2002; Stüben et al. 2002a, 2002b).

Chicxulub, a pre-K/T impact

The $\mathrm{K} / \mathrm{T}$ boundary transition at Yaxcopoil-1 is characterised by an incomplete record in which the $\mathrm{K} / \mathrm{T}$ boundary and early Danian are largely missing due to erosion and non-deposition. Nevertheless, the suevite 
breccia clearly predates the $\mathrm{K} / \mathrm{T}$ boundary. The latest Maastrichtian Zone CF1 planktic foraminiferal assemblages in the dolomitic limestone overlying the breccia indicate that the Chicxulub impact predates the $\mathrm{K} / \mathrm{T}$ boundary. The dolomitic limestones indicate normal marine sedimentation with periods of bioturbation, hardgrounds, erosion and the formation of glauconite layers. This reveals deposition over an extended time period during zone $\mathrm{CF} 1$, which spans the last $300 \mathrm{ky}$ of the Maastrichtian (Pardo et al. 1996). Impact ejecta (microtektites) layers from near the base of Zone CF1 have previously been documented from northeastern Mexico and suggest an age of about 65.3 Ma (Stinnesbeck et al. 2001; Keller et al. 2002) (Fig. 13).

Yax-1 demonstrates that the Chicxulub impact predates the $\mathrm{K} / \mathrm{T}$ boundary and is stratigraphically separated from the global $\mathrm{K} / \mathrm{T}$ impact layer and mass extinction, whereas microtektite layers from NE Mexico indicate that the impact occurred at about $65.3 \mathrm{Ma}$ (Keller et al. 2003). Other smaller late Maastrichtian craters have been recently reported from the Ukraine (Boltysh crater, Kelley and Gurov 2002) and from the North Sea (Silverpit crater; Stewart and Allen 2002). In addition, late Maastrichtian PGE anomalies have been reported from Oman (Ellwood et al. 2003). A possible early Danian (P. eugubina zone, approx. 64.9 Ma) impact event is recognised by PGE anomaly patterns in sections from Mexico, Guatemala and Haiti (Keller et al. 2001, 2003a; Stüben et al. 2002a; Stinnesbeck et al. 2002). There is thus increasing evidence that the end of the Cretaceous experienced multiple impacts (e.g., comet shower), rather than a single large impact as generally hypothesised.

How complete is the early Paleocene sediment sequence?

The $\mathrm{K} / \mathrm{T}$ boundary transition and early to middle Paleocene sediments at Yax-1 are characterised by an incomplete record (Fig. 10). The K/T boundary hiatus spans the earliest Danian zones P0 and P1a(1) ( 250ky missing) and probably the uppermost part of CF1. The upper zone Plc assemblage is juxtaposed over zone $\mathrm{P} 1 \mathrm{a}(2)$ and zones P1b and Pla(1) missing. Upsection, zones $\mathrm{P} 1 \mathrm{~d}$ and $\mathrm{P} 2$ are represented by less than $1 \mathrm{~m}$ of sediment, also suggesting an incomplete record and major erosion. Zone P3a appears to be more expanded, but contains reworked clasts with $\mathrm{P} 1 \mathrm{c}$ foraminiferal assemblages, indicating further erosion and redeposition of older Paleocene sediments. This condensed sedimentation is evident at Yax-1 in that $10 \mathrm{~m}$ of middle to outer
Fig. 13 Litho- and biostratigraphic correlation of the $\mathrm{K} / \mathrm{T}$ boundary transition between Yaxcopoil-1 and an idealised section in northeastern Mexico. Note that the oldest spherule layer in northeastern Mexico predates the $\mathrm{K} / \mathrm{T}$ boundary by 270-300 ky and that subsequent layers are likely reworked (Keller et al. 2003a). The $\mathrm{K} / \mathrm{T}$ boundary is characterised by a PGE anomaly (Ir about $1 \mathrm{ng} / \mathrm{g}$ ) and the extinction of tropical planktic foraminifera

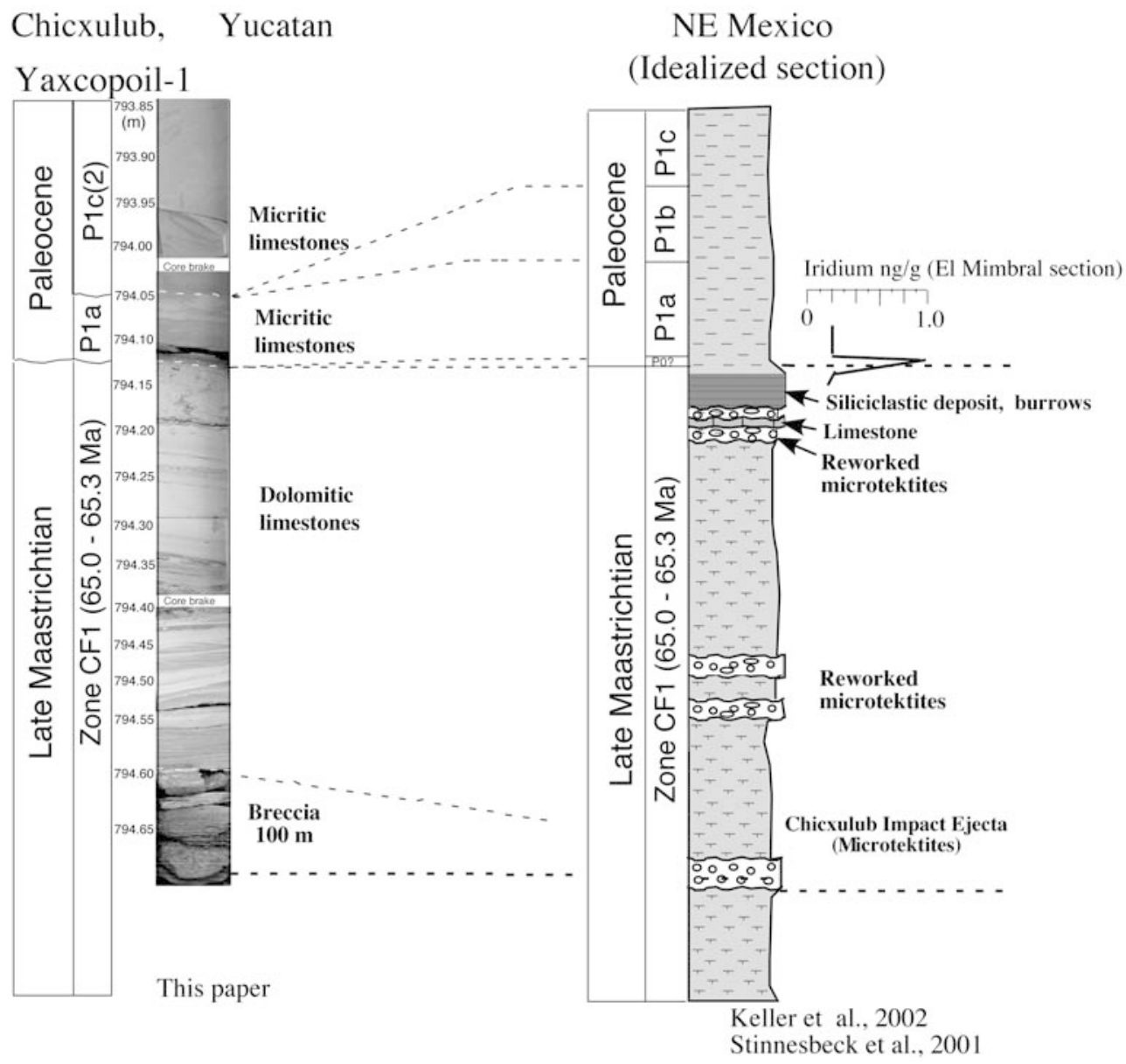


neritic lime mudstones represent a period of approximately 5 my of the Paleocene.

What caused this fragmentary sediment record? It is possible that sedimentation at Yax-1 occurred on a tectonic high, rather than in a crater-like depression. The reduced thickness of suevite unit $\mathrm{H}$, relative to other nearby cores, points to non-deposition or rapid erosion of a major portion of the suevite, prior to deposition of the limestone unit I. An elevated horst-like position of Yax-1 (Fig. 9) could also explain the absence of reworked suevitic breccia (unit $\mathrm{H}$ ) material in the Paleocene limestone sequence, the incomplete $\mathrm{K} / \mathrm{T}$ boundary record and reduced thickness and absence of early Paleocene faunal zones (e.g., P1a, P1d, P2).

The fragmentary sediment record is not unusual in the area. Cretaceous to Tertiary strata of many Caribbean and Gulf of Mexico DSDP sites are characterised by major hiatuses, which are attributed to funnelling of currents through the Straits of Florida and eustatic sea level fluctuations (Buffler et al. 1984; Worzel et al. 1973; Keller et al. 1993). Erosion and the depositional patterns of sediments in the entire region seem to be systematic, rather than random (Fig. 14). None of the deep sea sites cored in the area exhibits continuous sedimentation across the $\mathrm{K} / \mathrm{T}$ boundary, with zones P1b, P1d, P2 also generally reduced in thickness or missing (Keller et al. 1993). The K/T to Paleocene sedimentation and hiatus pattern of Yax-1 is thus strikingly similar to other Gulf of Mexico and Caribbean sections and may follow a regional pattern controlled by currents and sea level fluctuations (Fig. 14).

\section{Conclusions}

Litho- and biostratigraphic data from CSDP well Yaxcopoil-1 allow recognition of 10 major bio-and lithostratigraphic units between a depth of 775 and $1,511 \mathrm{~m}$, which provide the context for interpreting the effects of the Chicxulub impact and correlating subsurface sections across the northern Yucatan peninsula. Our observations and conclusions are as follows:

1. The Cretaceous sediment sequence at Yax-1 is represented by a sequence of limestones, dolomites and anhydrites of late Cretaceous ages. In addition to various carbonate platform environments (e.g., sabkha, lagoons), we identified a unit of open marine shelf sediments that was deposited during the latest Cenomanian $R$. cushmani zone.

2. The Cretaceous sediments are stratified and parautochthonous, with correlatable biohorizons over several hundred kilometres in northern and southern Yucatan. This supports the presence of normal deposition rather than an interpretation of chaotic megablocks sliding into the Chicxulub crater. The sediments are well preserved and did not suffer any strong thermal alteration as expected due to an impact.

3. Breccia units intercalated in the carbonate platform sequence show conformable and sometimes gradational contacts to under- and overlying non-brecciated sediments and appear to be of intraformational origin (e.g., dissolution of evaporites), rather than a
Fig. 14 Cretaceous-Paleogene sediment deposition and hiatus patterns based on planktic foraminiferal evidence in deep sea sections in the North Atlantic off Florida, the Gulf of Mexico and the Caribbean, and from PEMEX and CSDP wells of the Yucatan Peninsula. Note that the sediment record is highly fragmentary but shows a consistent regional pattern. Erosion and widespread hiati are probably linked to funnelled currents and sea level fluctuations (modified from Keller et al. 1993)

\section{AGE INTERVALS OF SEDIMENT DEPOSITION} Chicxulub Cores

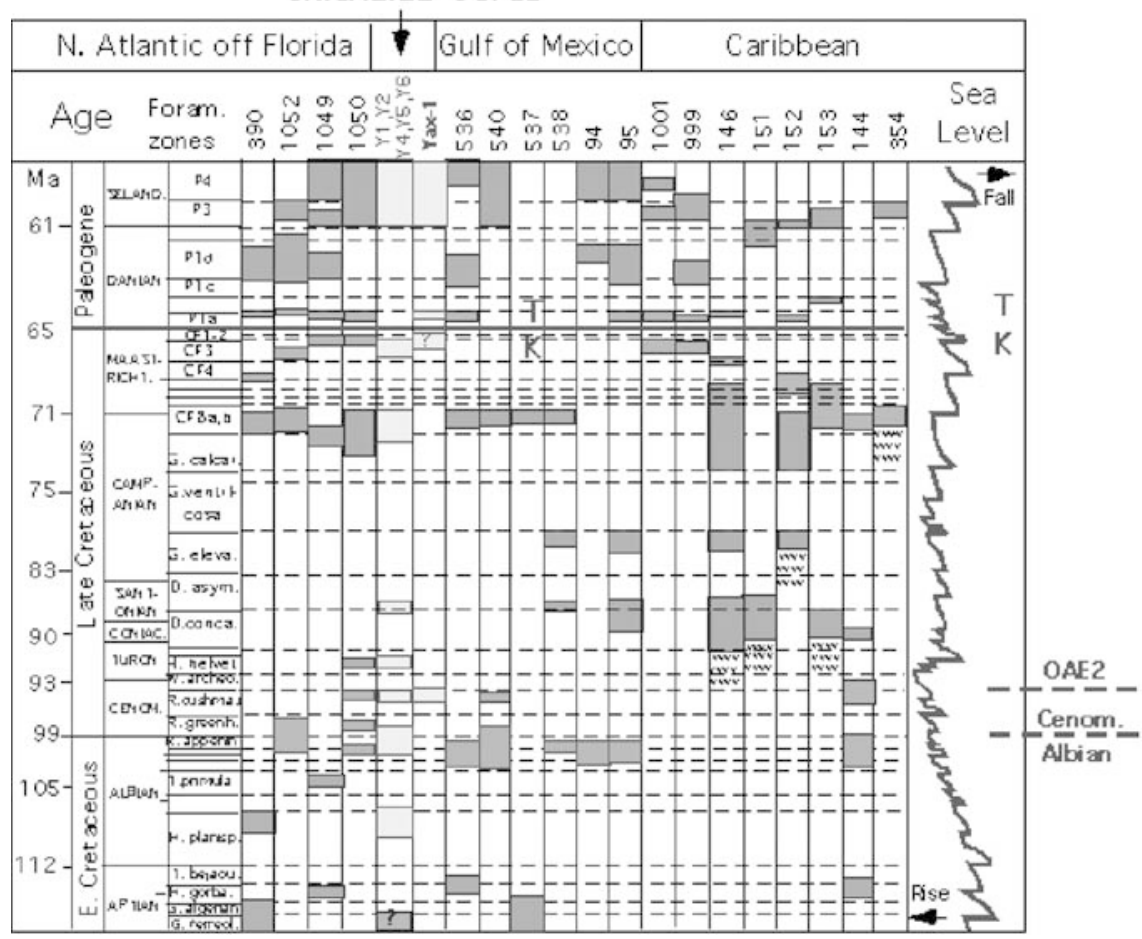


consequence of instant shaking, shearing and sliding of impact megablocks.

4. No glass spherules or altered glass shards, basement rocks or other exotic clasts and no melt rock have been detected below the suevitic impact breccia and only two suevitic breccia dykes were recognised close to the top of this $>600$-m-thick sediment sequence.

5. The suevitic impact breccia is $100 \mathrm{~m}$ thick, much less than in other wells in the area. The upper $15 \mathrm{~m}$ reveal upward-fining and reworking by ocean water.

6. The abrupt contact between suevite and overlying hemipelagic dolomitic limestones characterizes a hiatus. These carbonates contain latest Maastrichtian planktic foraminiferal assemblages (Plummerita hantkeninoides; zone CF1) deposited in situ, rather than reworked by backwash after the impact.

7. An erosional surface and dark grey-green glauconitic clay $50 \mathrm{~cm}$ above the breccia/dolomitic limestone contact marks the $\mathrm{K} / \mathrm{T}$ boundary and a hiatus. Limestones above this contact contain the first Tertiary planktic foraminifera indicative of an upper $P$. eugubina zone $\mathrm{P} 1 \mathrm{a}(2)$ age and deposition in an open marine shelf environment.

8. The P. eugubina Zone (P1a (2)) is only $6 \mathrm{~cm}$ thick. Upsection, another hiatus separates zone $\mathrm{P} 1 \mathrm{a}(2)$ and limestones of planktic foraminiferal Zone P1c. Zones $\mathrm{P} 1 \mathrm{c}$ to P3b are present up to a depth of $775 \mathrm{~m}$ and indicate increasingly more proximal conditions with debris flows from nearby shallow carbonate platform environments.

9. No evidence of post-impact compaction, mass sliding and subsequent shaking was recognised. The incomplete $\mathrm{K} / \mathrm{T}$ boundary and fragmentary Paleocene record may result from a horst position of Yax-1. However, incomplete sediment records are widely known from deep-sea wells in the Caribbean region as a result of currents.

Our data suggest that Yaxcopoil-1 is located outside the transient crater cavity and may even be located outside the annular crater trough, and that the Chicxulub crater may be smaller than previously estimated. Major disturbances of strata by the impact were confined to within less than $60 \mathrm{~km}$ of the proposed impact center. Furthermore, planktic foraminifera reveal a late Maastrichtian age for the Chicxulub crater and a stratigraphic separation from the $\mathrm{K} / \mathrm{T}$ boundary impact by up to $300 \mathrm{ky}$.

Acknowledgements We gratefully acknowledge access to the Yaxcopoil-1 core and logistic support during on site core analysis by the Instituto de Geofísica of the Universidad Nacional Autónoma de México.

This study has benefited from critical comments and suggestions by reviewer Paul Wignall and from discussions with A. Schafhauser, M. Caron, J.G. Lopez-Oliva, O. Morton and J. Urrutia-Fucugauchi. We thank M. Dadras (Institut de Microtechnique, Neuchâtel University, Switzerland for ESEM-EDX analyses. Research was supported by the German Science Foundation grants STI $128 / 7-1$ to 3 (WS), and STU $169 / 10-1$ to 3 (DS), the US NSF grant EAR-0207407 (GK), and the Swiss National Fund No. 8220-028367 (TA).

\section{References}

Adatte T, Stinnesbeck W, Keller G (1996) Lithostratigraphic and mineralogical correlations of near- $\mathrm{K} / \mathrm{T}$ boundary clastic sediments in northeastern Mexico: implications for megatsunami or sea level changes? Geol Soc Am Spec Pap 307:197210

Alvarez LW, Alvarez W, Asaro F, Michel HV (1980) Extraterrestrial cause for the Cretaceous-Tertiary extinction. Science 208:1095-1108

Boggs S (1987) Principles of sedimentology and stratigraphy. Merrill Publ Co, Columbus Toronto London Melbourne, 784 $\mathrm{pp}$

Bohor BF, Foord EF, Ganapathy R (1986) Magnesioferrite from the Cretaceous-Tertiary boundary, Caravaca, Spain. Earth Planet Sci Lett 81:57-66

Boynton WV (1991) Chicxulub crater: a possible Cretaceous/Tertiary Boundary impact crater on the Yucatan Peninsula. Geology 19:867-869

Brett R (1992) The Cretaceous-Tertiary extinction: a lethal mechanism involving anhydrite target rocks. Geochim Cosmochim Acta 56:3603-3606

Buffler RT, Schlager W et al. (1984) Initial reports Deep-Sea Drilling Project Volume 77: Washington, DC, US Government Printing Office, $747 \mathrm{pp}$

Chamley H (1989) Clay sedimentology. Springer, Berlin Heidelberg New York, 623 pp

Deer WA, Howie RA, Zussman J (1993) An introduction to the rock-forming minerals, 2nd edn. Longman Sci \& Tech, $696 \mathrm{pp}$

Dressler BO, Sharpton VL, Marín LE (2003) Chicxulub Yax-1 breccias: whence they come? Lunar Planet Sci 34, Abs 1259

Dressler BO, Sharpton VL, Morgan J, Buffler R, Moran D, Smit J, Stöffler D, Urrutia J (2003) Investigating a 65-Ma-old smoking gun: deep drilling of the Chicxulub Impact Structure. EOS (Trans Am Geophys Union) 84 (14) pp 125, 130

El Goresy A, Chao ECT (1976) Evidence of the impacting body of the Ries crater. The discovery of $\mathrm{Fe} \mathrm{Cr}$ Ni veinlets below the crater bottom. Earth Planet Sci Lett 31:330-340

Ellwood BB, MacDonald WD, Wheeler C, Benoist SL (2003) The $\mathrm{K}-\mathrm{T}$ boundary in Oman: identified using magnetic susceptibility field measurements with geochemical confirmation. Earth Planet Sci Lett 206:529-540

Espitalié J, Deroo G, Marquis F (1986) La pyrolyse Rock-Eval et ses applications. Partie 3. Revue Inst Fr du Pétrole 41:1

Fourcade E, Piccioni L, Escribá J, Rosselo E (1999) Cretaceous stratigraphy and palaeoenvironments of the Southern Petén Basin, Guatemala. Cretaceous Res 20:793-811

Haggerty SE (1976) Opaque minerals in terrestrial igneous rocks. MSA Short course notes, vol 4. In: Rumble III D (ed) Oxide minerals, vol 4. $\operatorname{Hg} 101,300 \mathrm{pp}$

Hay RL (1977) Geology of zeolites in sedimentary rocks MSA Short course notes. In: Mumpton F (ed) Mineralogy and geology of natural zeolites, vol 4, pp 53-64

Hildebrand AR, Penfield GT, Kring DA, Pilkington M, Camargo AZ, Jacobson SB, Boynton WV (1991) Chicxulub crater: a possible Cretaceous/Tertiary Boundary impact crater on the Yucatan Peninsula. Geology 19:867-869

Hsü KJ, He Q, McKenzie JA, Weissert H, Perch-Nilsen K, Oberhänsli H, Kelts K, LaBrecque J, Tauxe L, Krähenbuhl U, Percival SF Jr, Wright R, Karpoff A, Peterson N, Tucker P, Poore RZ, Gombos A Jr, Pisciotti K, Varman MF Jr, Schreiber E (1982) Mass mortality and its environmental and evolutionary consequences. Science 216:249-256

Iijima A (1980) Geology of natural zeolites and zeolitic rocks. Rees LVC (ed) Proceed 5th Int Conf Zeolites, Heyden, pp 103-118

Ivanov BA, Badukov D, Yakovlev OI, Gerasimov MV, Dikov YP, Pope K, Ocampo A (1996) Degassing of sedimentary rocks due to Chicxulub Impact: hydrocode and physical simulations. pp 125-140. In: Ryder G, Fastovsky D, Gartner S (eds) The Cretaceous-Tertiary Event and other catastrophes in earth history. Boulder, Colorado, Geol Soc Am Spec Pap 307 
Izett GA (1991) Tektites in the Cretaceous-Tertiary Boundary rocks on Haiti and their bearing on the Alvarez impact extinction hypothesis. J Geophys Res 96:20879-20905

Jarvis I, Carson GA, Cooper MKE, Hart MB, Leary PN, Tocher BA, Horne D, Rosenfeld A (1988) Microfossil assemblages and the Cenomanian-Turonian (Late Cretaceous) oceanic anoxic event. Cretaceous Res 9:3-103

Keller G, Adatte T, Stinnesbeck W, Affolter M, Schilli L, LopezOliva JG (2002) Multiple spherule layers in the late Maastrichtian of northeastern Mexico. Geol Soc Am Spec Publ 356:145-161

Keller G, Adatte T, Stinnesbeck W, Stüben D, Kramar U, Berner Z, Li L, Von Salis Perich-Nielsen K (1998) The CretaceousTertiary transition on the shallow Saharan Platform of Southern Tunisia. Geobios 30(7):951-975

Keller G, Adatte T, Stinnesbeck W, Stueben D, Berner Z (2001) Age, chemo- and biostratigraphy of Haiti spherule-rich deposits: a multi-event K-T scenario. Can J Earth Sci 38:197-227

Keller G, Li L, MacLeod N (1995) The Cretaceous/Tertiary boundary stratotype section at El Kef, Tunisia: how catastrophic was the mass extinction? Palaeogeogr Palaeoclimatol Palaeoecol 119:221-254

Keller G, MacLeod N, Lyons JB, Officer CB (1993) Is there evidence for Cretaceous/Tertiary boundary-age deep water deposits in the Caribbean and Gulf of Mexico? Geology 21:776-780

Keller G, Stinnesbeck W Adatte T, Stueben D (2003a) Multiple impacts across the Cretaceous-Tertiary boundary. Earth Sci Rev 62:327-363

Keller G, Stinnesbeck W, Adatte T, Holland B, Stüben D, Harting M, de Leon C, de la Cruz J (2003b) Spherule deposits in Cretaceous-Tertiary boundary sediments in Belize and Guatemala. Geol Soc Lond 160:783-795

Kelley PS, Gurov E (2002) Boltysh, another end Cretaceous impact. Science 37:1031-1043

Kenkmann T, Wittmann A, Scherler D, Schmitt RT (2003) Deformation features of the Cretaceous units of the ICDPChicxulub drill core Yax-1. Geophys Res Abs 5, 05098, European Geophys Soc 2003

Kring DA (1995) The dimensions of the Chicxulub impact crater and impact melt sheet. J Geophys Res 100:16979-16986

Kring DA (2000) Impact events and their effects on the origin, evolution, and distribution of life. GSA Today 10:2-5

Kübler B (1987) Cristallinite de l'illite, méthods normalisées de préparations, méthodes normalisées de measures. Neuchâtel, Suisse, Cahiers Inst Géologie, Sér ADX 1, 13 pp

Kübler B (1997) Concomitant alteration of clay minerals and organic matter during burial diagenesis. In: Paquet $\mathrm{H}$, Clauer $\mathrm{N}$ (eds) Soils and sediments. Springer, Berlin Heidelberg New York, pp 327-363

Kyte FT, Smit J (1986) Regional variations in spinel composition: an important key to the Cretaceous-Tertiary event. Geology $14: 485-487$

Lafargue E, Espitalié J, Marquis F, Pillot D (1996) Rock-Eval 6, applications in hydrocarbon exploration, production and soil contamination studies Vinci Technologies, Rock-Eval user's manual

Lopez Ramos E (1973) Estudio geológico de la Peninsula de Yucatan. Bol Assoc Mex Geol Petrol 25 (1-3):23-76

Lopez Ramos E (1975) Geological summary of the Yucatan Peninsula, In: AEM Nairn, Stehli FG (eds) The ocean basins and margins, vol 3. The Gulf of Mexico and the Caribbean. Plenum Press, New York, pp 257-282

Marín LE, Sharpton VL, Urrutia-Fucugauchi J, Sikora P, Carney C (1994) The "Upper Cretaceous Unit" in the Chicxulub Multiring Basin: new age based on planktic foraminiferal assemblage. Lunar Planet Inst, LPI Contrib 825:77

Marshall RH (1974) Petrology of subsurface mesozoic rocks of the Yucatán platform, Mexico, MS Thesis, New Orleans, Louisiana, Univ of New Orleans, $97 \mathrm{pp}$

Meyerhoff AA, Lyons JB, Officer CB (1994) Chicxulub structure: a volcanic sequence of late Cretaceous age. Geology 21:3-4
Morgan J, Buffler R, Urrutia-Fucugauchi J, Grieve R (2002) Chicxulub: drilling the K-T Impact Crater Instituto de Geofísica, Universidad Nacional Autónoma de México, Serie: Infraestructura Científica y Desarrollo Tecnológico 4, 39 pp

Morgan J, Warner M (1999) Chicxulub: the third dimension of a multi-ring impact basin. Geology 27:407-410

Odin GS (1975) Les glauconies, PhD Thesis. P et M Curie Univ, Paris, $251 \mathrm{pp}$

Pardo A, Ortiz N, Keller G (1996) Latest Maastrichtian and Cretaceous-Tertiary foraminiferal turnover and environmental changes at Agost Spain. In: MacLeod N, Keller G (eds) Cretaceous-Tertiary boundary mass extinction: biotic and environmental changes. Norton Press, New York, pp 139-171

Pierrazo E, Kring DA, Melosh HJ (1998) Hydrocode modeling of Chicxulub as an oblique impact event and the production of climatically active gases. J Geophys Res 103:28607-28625

Pope KO (2002) Impact dust not the cause of the CretaceousTertiary mass extinction. Geology 30(2):99-102

Pope KO et al. (1997) Energy, volatile production, and climatic effects of the Chicxulub Cretaceous-Tertiary impact. J Geophys Res 102:21645-21654

Rebolledo Vieyra M, Urrutia-Fucugauchi J, Marín L, Trejo García A, Sharpton VL, Soler-Arechalde AM (2000) UNAM scientific shallow drilling program of the Chicxulub impact crater. Intl Geol Rev 42:928-940

Reed SJB (1996) Electron microprobe analysis and scanning electron microscopy in geology. Cambridge Univ Press, $201 \mathrm{pp}$

Robin E, Boclet D, Bonte Ph, Froget L, Jehanno C, Rocchia R (1991) The stratigraphic distribution of Ni-rich spinels in Cretaceous-Tertiary boundary rocks at El Kef (Tunisia), Caravaca (Spain) and Hole 761 C (Leg 122). Earth Planet Sci Lett 107:715-721

Romein AJT, Smit J (1981) Carbon-oxygen stable isotope stratigraphy of the Cretaceous-Tertiary boundary interval: data from Biarritz section (SW France). Geol Mijnbouw 60:514-544

Schackleton NJ, Hall MA (1984) Carbon isotope data from Leg 74 sediments. In: Moore Jr et al. (eds) Initial Reports Deep Sea Drilling Project 74:613-619

Schafhauser A, Stinnesbeck W, Holland B, Adatte T, Remane J (2004) Lower Cretaceous pelagic limestones in southern Belize: proto-Caribbean deposits on the southeastern Maya block. Am Assoc Petrol Geol Mem (in press)

Schlanger SO, Arthur MA, Jenkyns HC, Scholle PA (1987) The Cenomanian-Turonian anoxic event. Stratigraphy and distribution of organic carbon-rich beds and the marine $\mathrm{d} 13 \mathrm{C}$ excursion. In: Brooks J, Fleet JA (eds) Marine petroleum source rocks. Am Assoc Petrol Geol Bull 64:67-87

Sharpton VL, Marin LE, Carney C, Lee S, Ryder G, Schuraytz BC, Sikora P, Spudis PS (1996) A model for the Chicxulub impact basin based on evaluation of geophysical data, well logs and drill core samples. pp 55-74. In: Ryder G, Fastovsky D, Gartner S (eds) The Cretaceous-Tertiary event and other catastrophes in earth history. Boulder, Colorado, Geol Soc Am Spec Pap 307

Sial AN, Ferreira VP, Toselli AJ, Parada MA, Acenolaza FG, Pimentel MM, Alonso RN (2001) Carbon and oxygen isotope compositions of some Upper Cretaceous-Paleocene sequences in Argentina and Chile. Intl Geol Rev 42(10):892-909

Sigurdsson H, Bonté P, Turpin L, Chaussidon M, Metrich N, Steinber M, Pradel P, D'Hondt S (1991) Geochemical constraints on source region of Cretaceous/Tertiary impact glasses. Nature 353:839-842

Sigurdsson H, D'Hondt S, Carey S (1992) The impact of the Cretaceous/Tertiary bolide on evaporite terrane and generation of major sulfuric acid aerosol. Earth Planet Sci Lett 109:543-559

Smit J (2004a) Not a single shred... In: The Great Chicxulub debate. Geol Soc Lond, Internet debate: http://www.geolsoc.org.uk/template.cfm?name $=$ NSG2349857238495

Smit J (2004b) Chicxulub drilling CSDP, Transition impact to post impact rocks: are controversies real? IODP/ICDP Joint Colloquium (Bremen), IODP-Contributions and Abstracts 
Smit J, Dressler B, Buffler R, Moran-Zenteno D, Sharpton VL, Stöffler D, Urrutia J, Morgan J (2002) Yaxcopoil-1 drill hole in the Chicxulub impact crater. Geol Soc Am Abstr Progr

Smit J, Lustenhouwer WJ, van der Gaast SJ (2004) Transition of the impact to post-impact rocks in the Yaxcopoil-1 drill hole: no evidence for pre-K/T age of the Chicxulub crater. Geophys Res Abs 6, 03184, EGU, Nice

Srodon J, Eberl DD (1987) Illite. In: Bailey SW (ed) Micas. Rev Mineral 13, Miner Soc Am Washington, DC, 584 pp

Stewart SA, Allen JP (2002) A 20-km-diameter multi-ringed impact structure in the North Sea. Nature 418(1):520-523

Stinnesbeck W, Keller G, de la Cruz J, de Leon, C, MacLeod N, Whittacker JE (1997) The Cretaceous-Tertiary boundary in Guatemala-Limestone breccia deposits from the South Peten Basin. Geol Rund 86:686-709

Stinnesbeck W, Keller G, Schulte P, Stüben D, Berner Z, Kramar U, Lopez-Oliva JG (2002) The Cretaceous-Tertiary (K/T) boundary transition at Coxquihui, state of Veracruz, Mexico: evidence for an early Danian impact event? J South Am Earth Sci, pp 497-509

Stinnesbeck W, Schulte P, Lindenmaier F, Adatte T, Affolter M, Schilli L, Keller G, Stüben D, Berner Z, Kramar U, LopezOliva JG (2001) Late Maastrichtian age of spherule deposits in northeastern Mexico: implication for Chicxulub scenario. Can J Earth Sci 38:229-238

Stöffler D, Hecht T, Kenkmann RT, Schmitt T, Wittmann A (2003) Properties, classification, and genetic interpretation of the allochthonous impact formations of the ICDP Chicxulub drill core Yax-1. Geophys Res Abs 5, Nr 07237

Stüben D, Kramar U, Berner Z, Eckhardt D, Stinnesbeck W, Keller G, Adatte T, Heide K (2002a) Two anomalies of platinum group elements above the Cretaceous-Tertiary boundary at Beloc, Haiti: geochemical context and consequences for the impact scenario. Geol Soc Am Spec Pap 356:163-188
Stüben D, Kramar U, Berner Z, Stinnesbeck W, Keller G, Adatte T (2002b) Trace elements, stable isotopes, and clay mineralogy of the Elles II K/T boundary section in Tunisia: Indications for sea level fluctuations and primary productivity. Palaeogeogr Palaeoclimatol Palaeoecol 178(3-4):321-345

Swisher CC, Grajales-Nishimura JM, Montanari A, Margolis SV, Claeys P, Alvarez W, Renne P, Cedillo-Pardo E, Maurasse FJ-M, Curtis GH, Smit J, Williams MO (1992) Coeval ${ }^{40} \mathrm{Ar} /{ }^{39} \mathrm{Ar}$ ages of 65.0 million years ago from Chicxulub crater melt rock and Cretaceous-Tertiary boundary tektites. Science 257:954-958

Urrutia-Fucugauchi J, Marín L, Trejo-García A (1996) UNAM Scientific drilling program of Chicxulub impact structure-evidence for a 300 kilometre crater diameter. Geophys Res Lett 23(13):1565-1568

Urrutia-Fucugauchi J, Morán-Zenteno D, Sharpton V, Buffler R, Stöffler D, Smit J (2001) The Chicxulub Scientific Drilling Project Instituto de Geofísica, Universidad Nacional Autónoma de México, Serie: Infraestructura Científica y Desarrollo Tecnológico 3, $45 \mathrm{pp}$

Utada M (2001) Zeolites in hydrothermally altered rocks. In: Bish DL, Ming DW (ed) Natural zeolites. Rev Mineral Geochem 45 , Mineral Soc Am Washington, DC, 654 pp

Ward W, Keller G, Stinnesbeck W, Adatte T (1995) Yucatan subsurface revisited: implications and constraints for the Chicxulub meteor impact. Geology 23:873-876

Welton EJ (1984) The AAPG methods in exploration series, 4 $237 \mathrm{pp}$

Wittmann A, Kenkmann T, Schmitt RT, Stöffler D (2003) Clastic polymict dikes in the "megablock" sequence of the ICDPChicxulub drill core Yax-1. Geophys Res Abstr, vol 5, Nr 05223, Eur Geophys Soc

Worzel JL, Bryant W et al. (1973) Initial Reports of the Deep Sea Drilling Project, vol 10, Washington, DC, US Government Printing Office, $747 \mathrm{pp}$ 